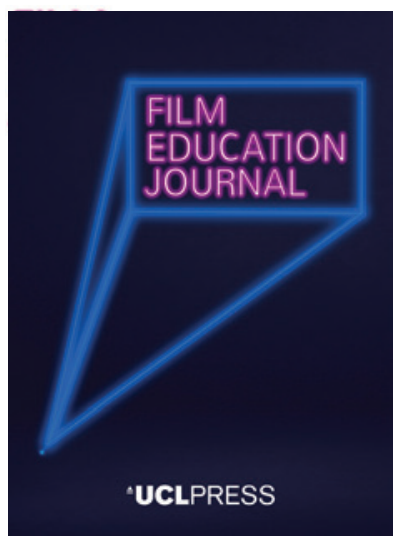

UCLPRESS

FILM EDUCATION JOURNAL

ISSN 2515-7086 (Online)

Journal homepage:

https://www.uclpress.co.uk/pages/film-education-journal

\title{
Taking wonders to the margins (Maravillas al Margen)
}

\section{Alicia Vega}

\section{How to cite this article}

Vega, A. (2020) 'Taking wonders to the margins (Maravillas al Margen)'. Film Education Journal, 3 (2), 87-122. Online. https://doi.org/10.14324/FEJ.03.2.01

Submission date: 11 March 2020

Acceptance date: 12 May 2020

Publication date: 26 November 2020

\section{Peer review}

This article has been peer-reviewed through the journal's standard double-blind peer review, where both the reviewers and authors are anonymized during review.

\section{Copyright}

(C) 2020 Vega. This is an open-access article distributed under the terms of the Creative Commons Attribution Licence (CC BY) 4.0 https://creativecommons.org/licenses/by/4.0/, which permits unrestricted use, distribution and reproduction in any medium, provided the original author and source are credited.

\section{Open access}

The Film Education Journal is a peer-reviewed open-access journal. 


\title{
Taking wonders to the margins (Maravillas al Margen)
}

\author{
Alicia Vega* \\ First published in Taller de cine para niños (Vega, 2018) \\ Translated from Spanish by Antonio Lázaro-Reboll
}

\begin{abstract}
Translated into English for the first time, this article by film educator and outreach worker Alicia Vega describes her experiences conducting a series of Cinema Workshops in highly disadvantaged communities across Chile, which sought to provide younger children with early, formative understandings of cinema. A rich account of the experience, incorporating a variety of images drawn from the workshops, the article provides an intimate, detailed reflection on a remarkable film education and humanitarian endeavour. It concludes with a series of testimonials from children who participated in the project, as well as from their parents and other participants.
\end{abstract}

Keywords: Chile, outreach, children, film education, Chaplin, Lumière brothers, early cinema

\section{Editor's note}

This article adopts a non-traditional format in placing a series of photographs in counterpoint to its written account of the workshops. These photographs are not tied to the text as figures, but rather are intended to give readers an immersive sense of both the content of the workshops and the circumstances in which they took place. This format is also more in keeping with the original 2018 publication. Note that the text was written in 2012 and refers in the present tense to workshops that were taking place at the time but are no longer running.

It never crossed my mind that the Taller de Cine (Cinema Workshop) would lead to children becoming film directors, actors and actresses, editors or any of the other occupations related to the profession. When I first started the Taller de Cine workshop in the parish of Jesús Carpintero in the Huamachuco District (Libertad Region, Peru) back in 1985, I longed for a space where fun, emotion and art could come together for children.

The main achievements of the workshops certainly include that children experienced an increase in their self-esteem, developed their creativity and learnt some fundamental values, such as working in a team. But our main objective, which was fundamental to us, was that the children had a good time. Their cost-free status, so dear to art, is for me the most valuable feature of these workshops since they came to life 27 years ago. 
The workshop's methodology has been the same since its inception, apart from some changes in the programming of films or in finding a suitable venue for the activities. The Taller de Cine runs once a week for seven months when it is held in a city, and is held daily for a month without a break during the summer period, usually in a rural area. It is conceived and planned as a project for a community, drawing in around 250 participants. The dynamics of the workshop are always the same: the children watch a film per session and undertake specific activities related to learning about a highly technical medium; they work together within the same space with a view to promoting a communal spirit; further, they are divided into two groups, of younger and older children.

The workshop was originally designed for pupils between the ages of 5 and 12, although we accept children slightly over or under those ages on many occasions, usually for one of two reasons: first, to satisfy quotas, for it would be unnecessary to stop a 13 year old from attending if only 40 participants had signed up; and, second, to provide support to those parents who are unable to leave their children with anybody else while they are at work, especially if siblings are participating in the workshop. From 2000, the maximum age allowed has been 10, for children nowadays seem to be more precocious.

The key point of the workshop is for children to play around with images and to realize that moving images have always engaged human beings. How can a photograph of a horse or a bicycle acquire movement? This is the type of question that concerned those nineteenth-century scientists who managed to create a number of toys inspired by the optical illusion described as persistence of vision. These toys included the invention of the thaumatrope, whose etymological root means a 'wonder' (thauma) that 'rotates' (trope). The thaumatrope consists of a disc with a different picture on each of its two sides, which appear to combine into one image when the

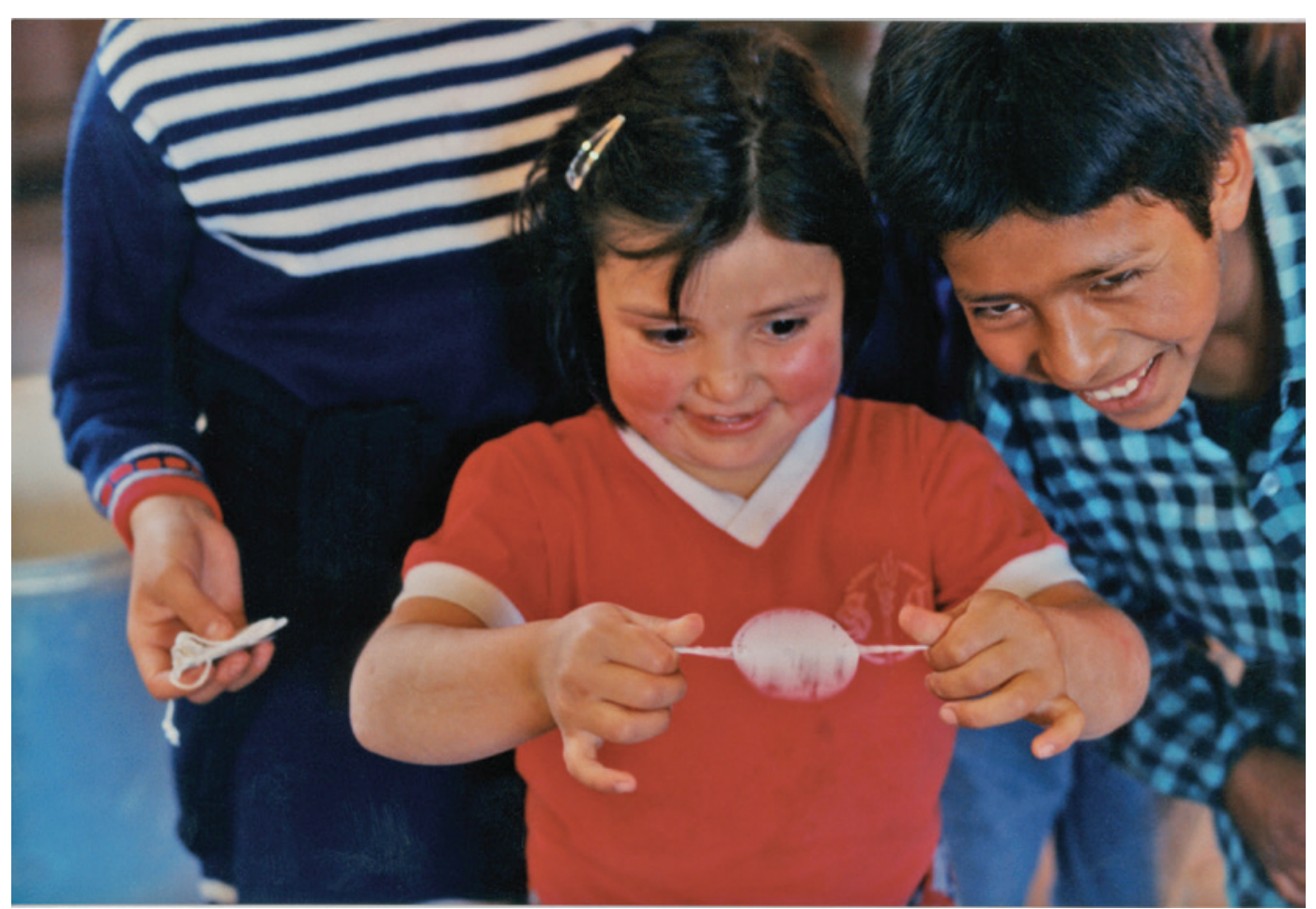

The thaumatrope game, Ciudad del Niño, 1996 
disc is rapidly rotated by the strings that hold it. The thaumatrope was invented in 1824 by the British physician John Ayrton Paris, whose best-known example is the bird-incage thaumatrope: a bird on one side and a cage on the other combine so that the bird appears to be in a cage. As with the bird-in-cage optical toy, the children also enjoy the bald-man optical effect, where a bald man and his wig combine to make it look like he has ample hair. Such examples encourage children in the workshop to produce their own thaumatropes: a football going into the net, a smiling fish, the sun rising over a mountain, as well as - perhaps unavoidably given situations in their own lives - images such as a child crying or a man imprisoned.

Among the games we suggest the children design at the manual craft sessions we include some examples of nineteenth-century inventions inspired by the persistence of vision illusion, such as the zoetrope (literally, 'live turning'), the magic roll and the kinetoscope. Another nineteenth-century optical toy children have the chance to design is a zoetrope. The zoetrope produces the illusion of movement when one views a band of images from a set of sequenced pictures through narrow slits in a rotating cylinder. As the cylinder spins, the user looks through these slits at the pictures on the other side of the cylinder, seeing a rapid succession of images producing the illusion of motion. The word zoetrope can also be taken to mean 'wheel of life'.

In 1893, Edison printed a series of photographs of a man sneezing onto a strip of film. This was the origin of the kinetoscope. One of the children's favourite activities in the workshop is the cuncuna (caterpillar), where they design a row or line of images between 20 and 50 metres long, made up of a frame-by-frame sequence they have created: the flu vaccine, floods, a protest day/demonstration. As with many other activities, children realize through the cuncuna task that a film, that is to say, a long strip, consists of stills.

Our first contact session with the children focuses on exploring what an image is. I usually take a blown-up photo of a hat and ask them to tell me what it is. They all shout aloud 'a hat'. Then, as if by magic, I bring out a top hat from a basket and ask them again if they can tell me what it is. 'A hat,' they reply in unison. When I ask them which of the two hats is the real one, they immediately realize that the former is only the image of a hat, whereas the latter is the real thing. Soon afterwards they try it on and walk around the classroom with it on their heads. This always makes me laugh because

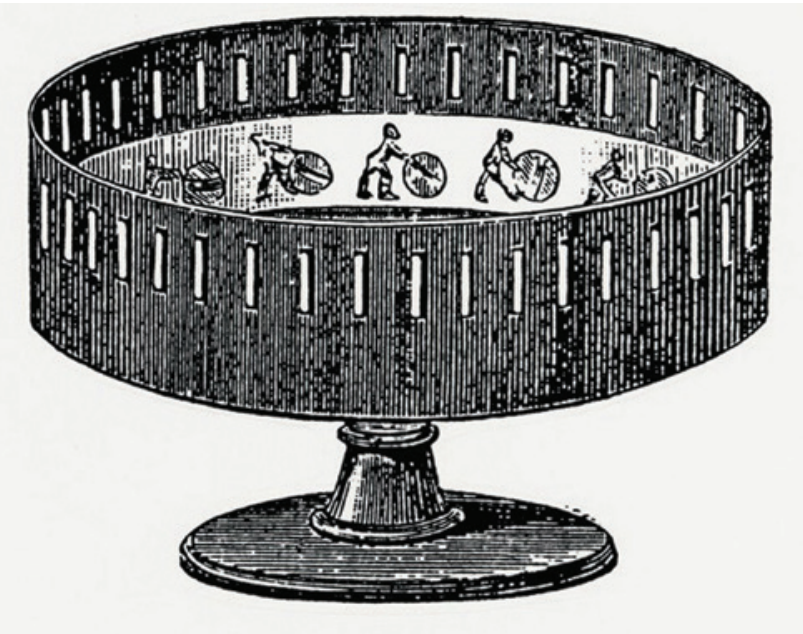

A traditional zoetrope 


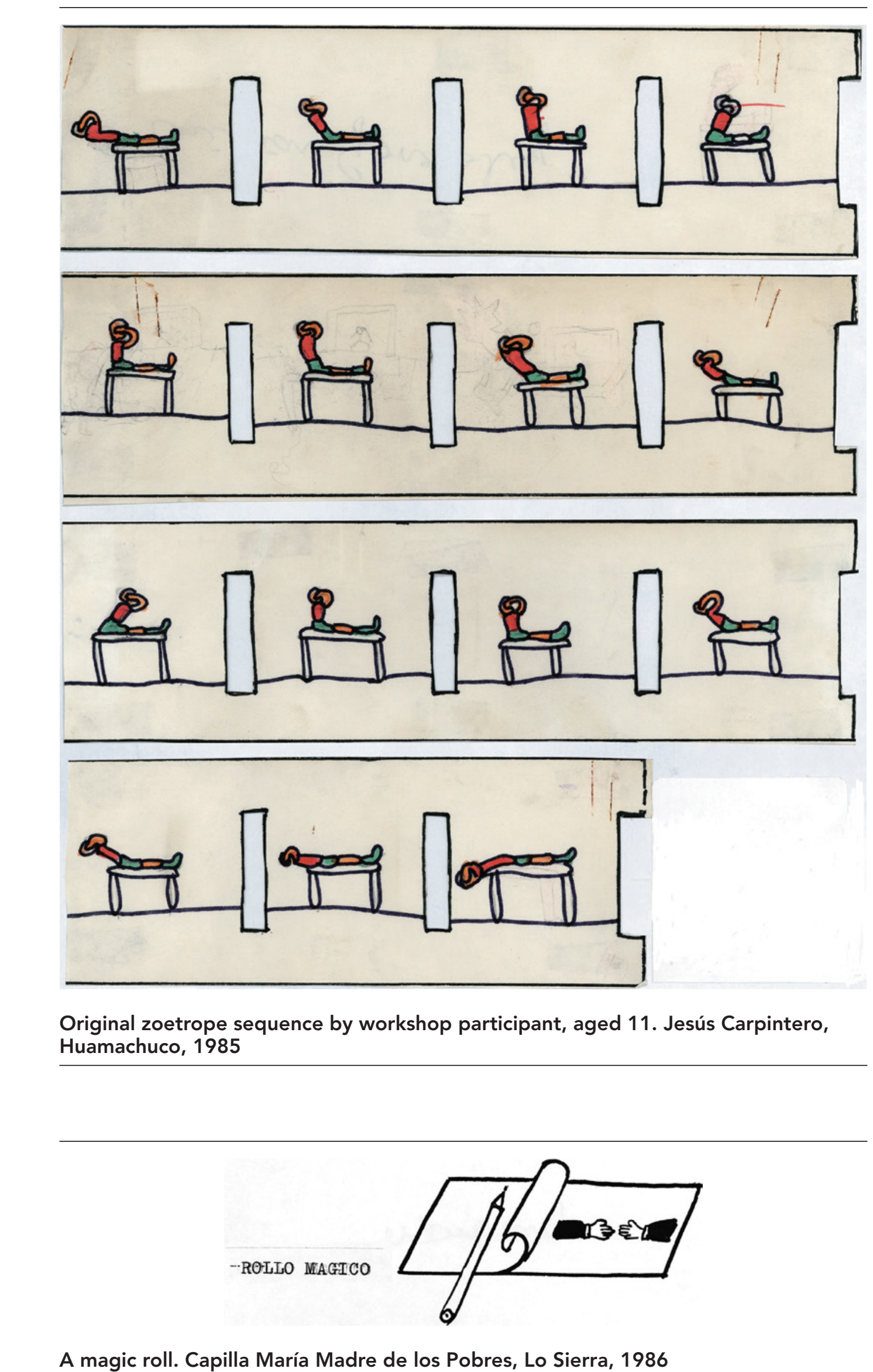



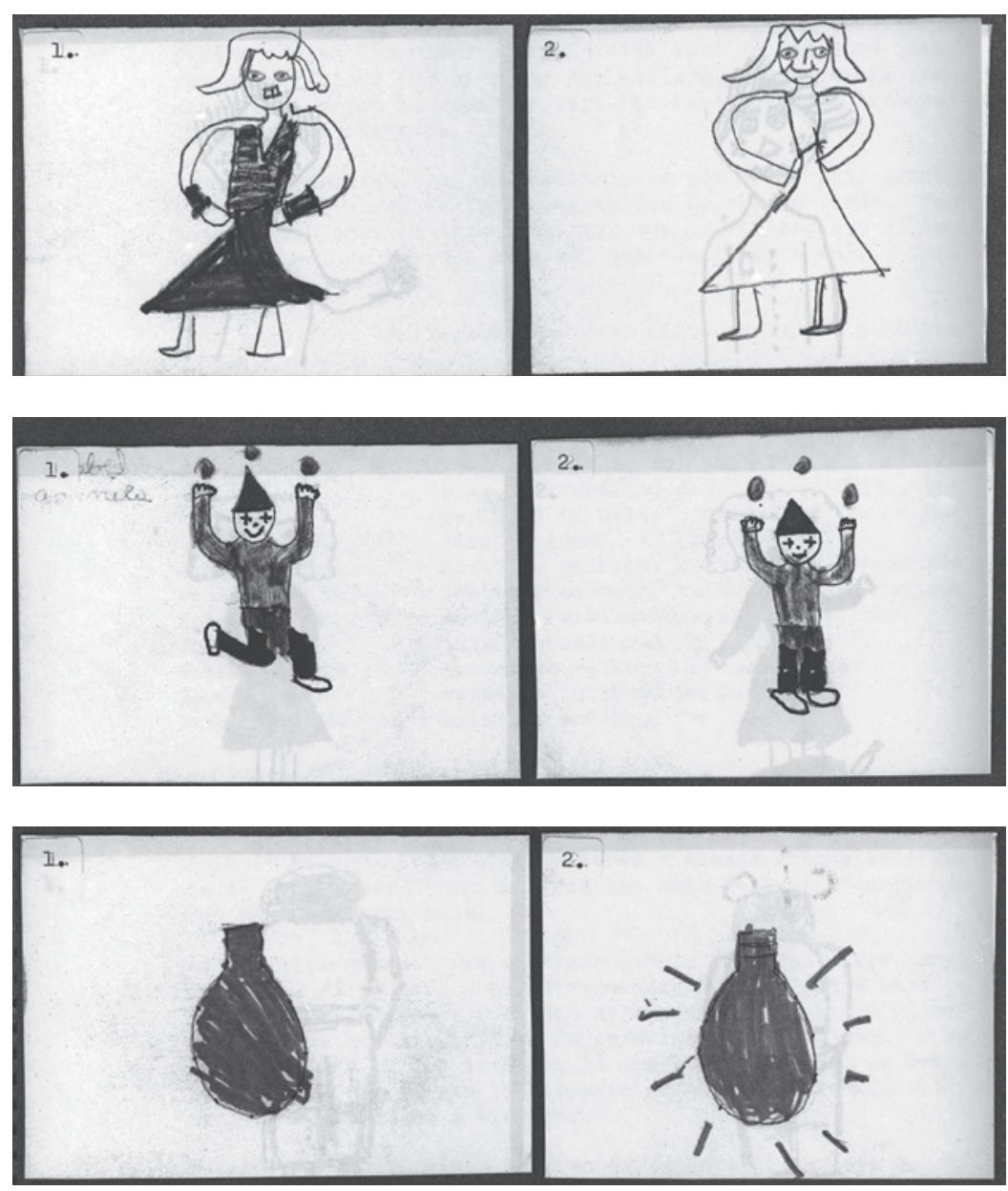

Magic rolls designed by workshop participants aged 11, 10 and 6. Capilla Maria Madre de los Pobres, Lo Sierra, 1986

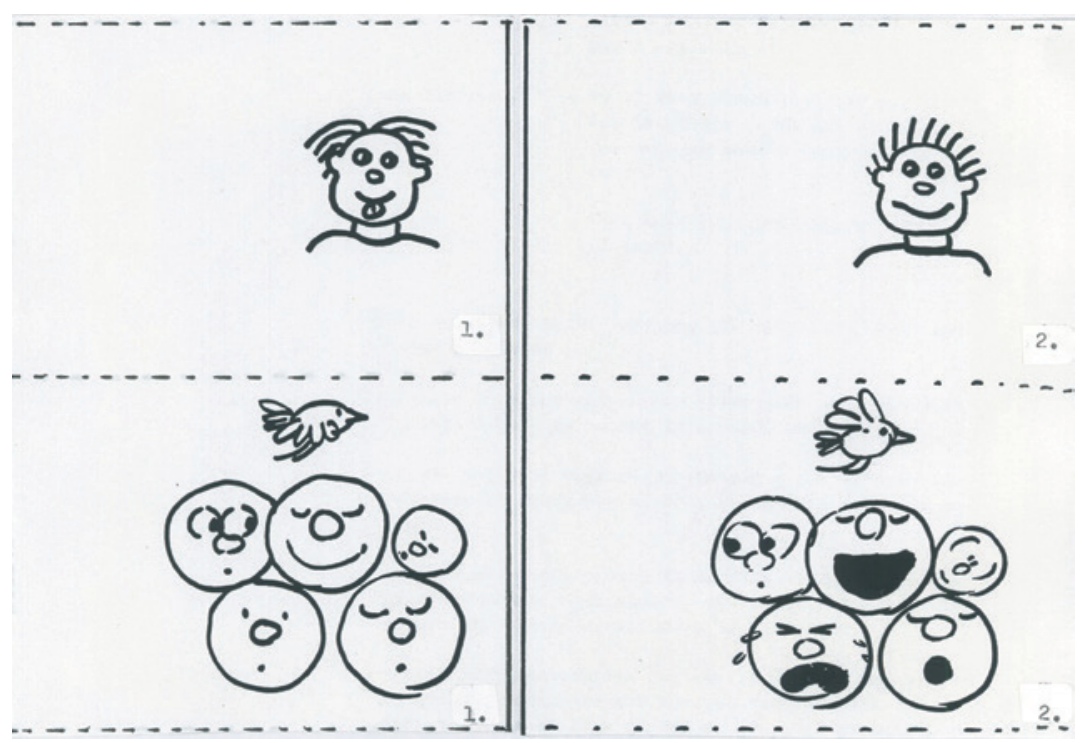

Model magic rolls designed for the children by the animation illustrator José Domingo Ulloa, Director of the Department of Animation of Televisión Nacional de Chile (TNC). During the subsequent workshop the children created their own designs. Capilla Jesús Carpintero, Huamachuco, 1986 


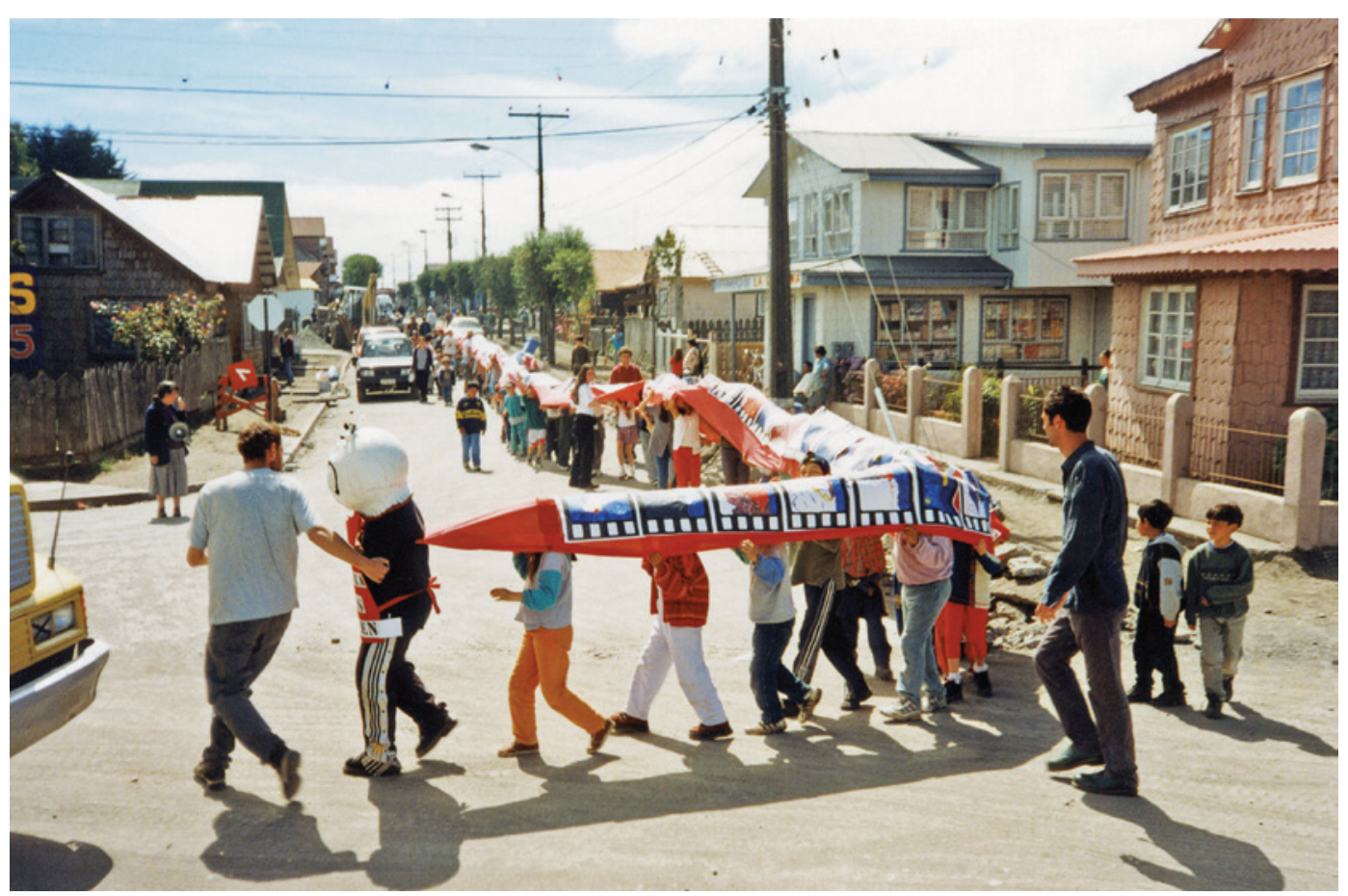

The caterpillar game. The activity consists of joining the stills drawn by the children in order to make a film strip and to parade it through the village streets. Queilén, 2000

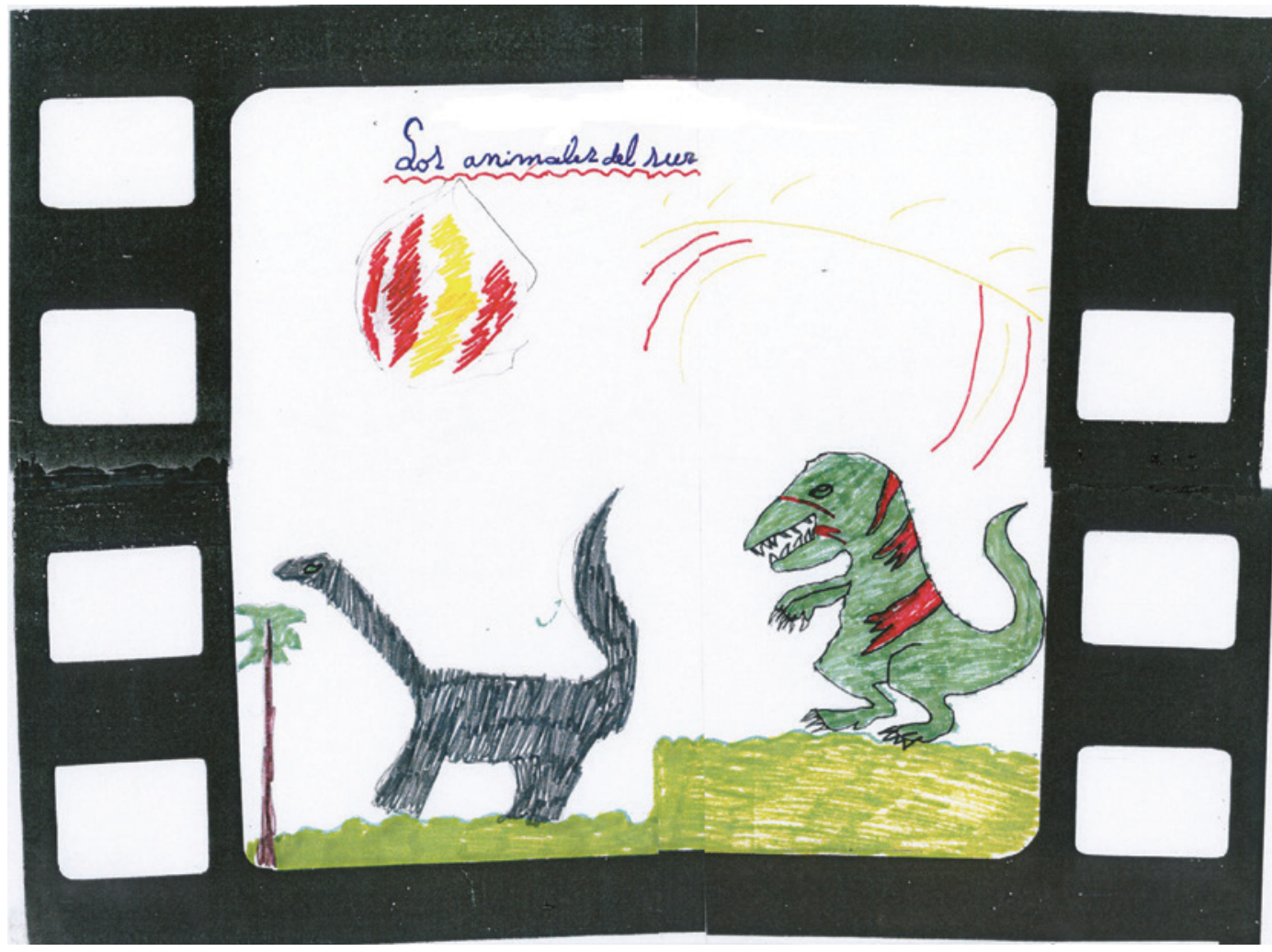

A frame from the cuncuna. Alonso de Ercilla, Castro Alto, 2005 
these top hats are made with beaver fur and have come all the way from museums in Europe and nobody should really play with them. But these children always wear hats, almost a privilege among their multiple deprivations.

Through games like the thaumatrope or the magic block, which the children find particularly fascinating, the participants soon understand that images can move, and that images can express ideas as well as convey different meanings, depending on the framing or type of shot being used, on the camera movement or on coordinating shots to produce a scene.

Towards the end of the workshop, the children understand that cinema is not an innocent medium but rather that images have intent.

All the workshop activities require the use of expensive equipment, otherwise the final products would be poor quality. It is important that all participants have access to appropriate equipment. When the project first started, somebody would give me a blue pair of scissors, somebody else would give me a yellow one, another person a red one. The same would happen with different types of cardboard or glue. As we depended on donations, we could not demand more. But I soon realized that this approach did not work. On the one hand, there was a visible difference in the quality of some of the materials, and, on the other, there were too many children arguing over the materials when setting up the activities - children being children. Those with the green pair of scissors wanted the red one and those with the red pair preferred the blue one... They thought there was discrimination.

I remember vividly one of our first courses where we organized a raffle in which the prize was a remote-control helicopter that we had used to provide an example of movement in one of the activities. Sadly, since all the children pounced on the winner, the helicopter was completely destroyed. That day we learnt a valuable lesson: we cannot provide one thing solely for one person. Similar situations arose with the distribution of Super-8 cameras.

When I saw them arguing over the materials, I figured out that the best way to proceed was to purchase the same items for everybody. Even small things like this give you fascinating insights into the children's minds, and sometimes by sheer luck. For example, when I was buying the textiles to make the bags for the children to keep their stationery, I found a checked black-and-white fabric. Even though I was not completely convinced by it, I purchased this fabric. Bags made from this fabric then turned out to be the most successful in the history of the workshop. Why? Because they were in the colours of the Colo-Colo football team.

The workshop has always included a team of instructors, mainly university students, who are paid for their work. Remuneration ensures their commitment to the project as well as their attendance every week. Each instructor has a role: some attend to the parents who are outside the venue, some help with manual tasks or with snack time, others are in charge of first aid, and others operate the projector or document the process.

Our general policy is to treat everybody equally and to respect diversity. This is essential in a context where, among others, there are children of Araucanian origin, children who cannot yet read or write, and children of prison inmates, prostitutes, police officers and drug traffickers. The most important rule that governs our pedagogy is not to interfere in the personal work of the participants: freedom is essential, even if they refuse to engage with any activity. Sometimes we select certain children to collaborate with the instructors, helping with simple tasks such as the distribution of materials or tidying up. This form of integration is not always possible, however, because sometimes there is some stealing of equipment and food. Most children, however, return all the material. 


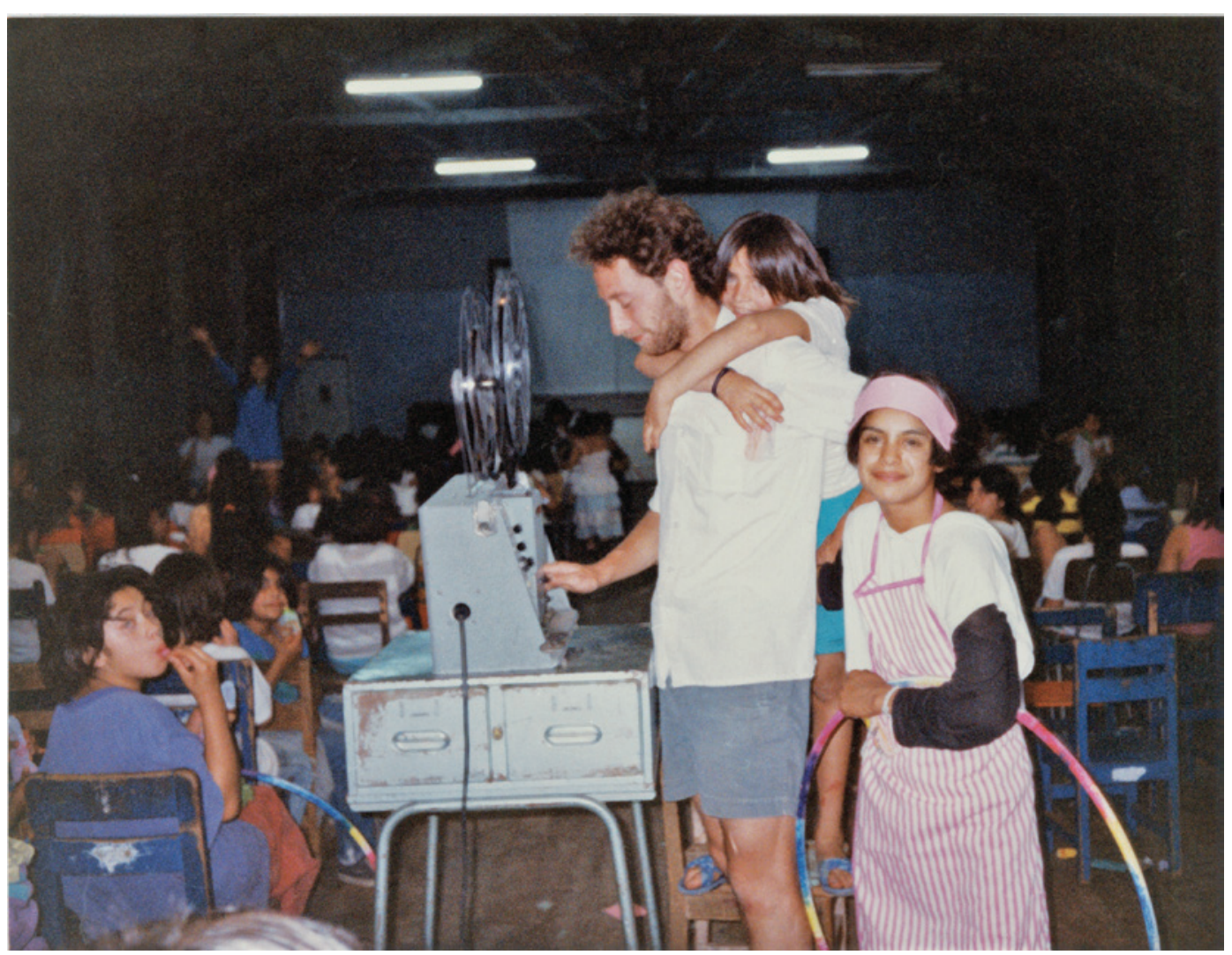

Instructor and cameraman Sebastián Ortega setting the $16 \mathrm{~mm}$ projector up for the film exhibition. As the workshop progressed, both boys and girls started asking him what film he was going to show, which country the film was coming from, when it had been made and who made it.

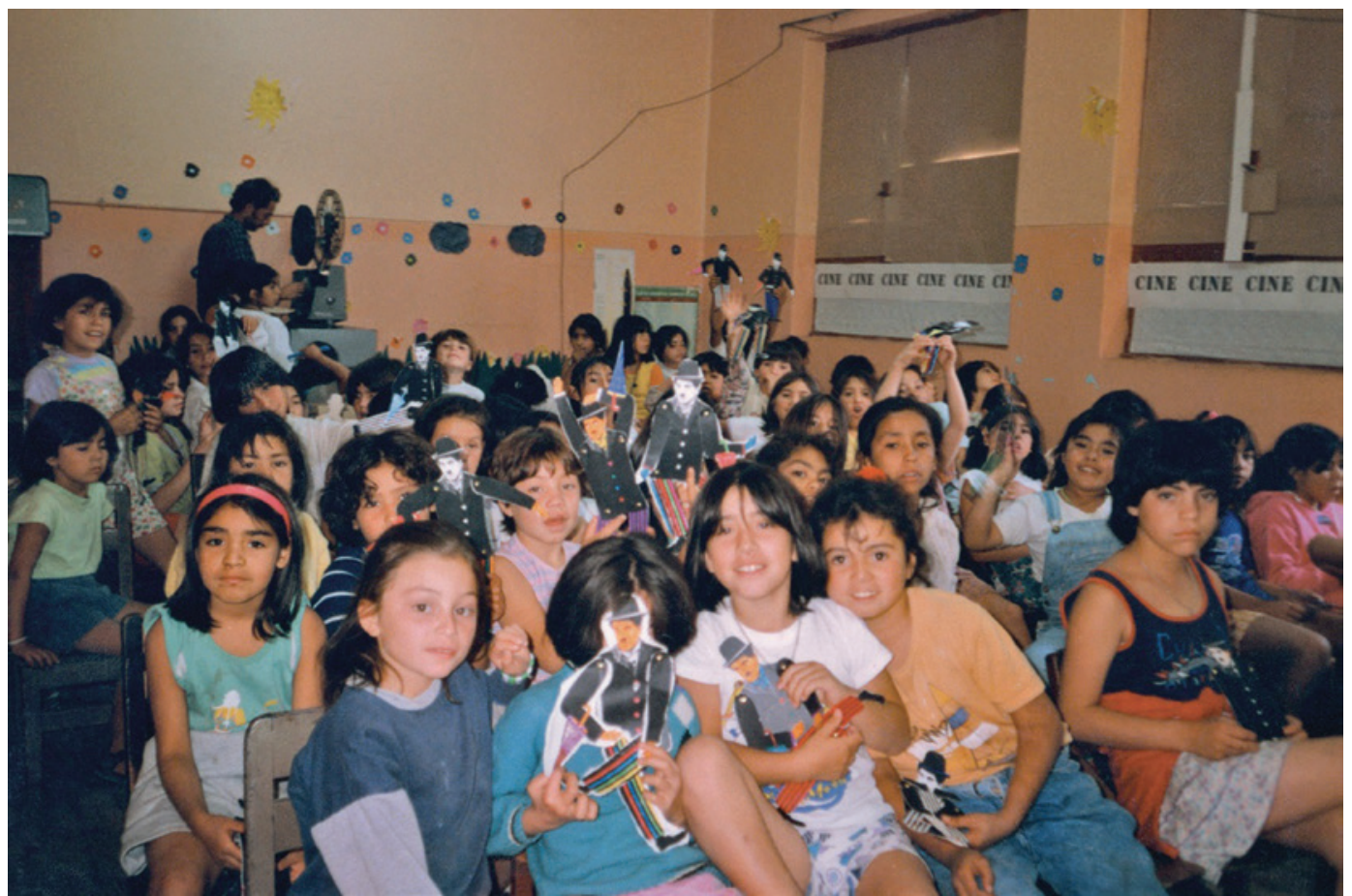

Workshop participants, Ciudad del Niño, 1998 
Miopinion es muy vueno el cine y los tios y la tia, las tias, Callantun. El tio questaba ablando es gueno . (-)".

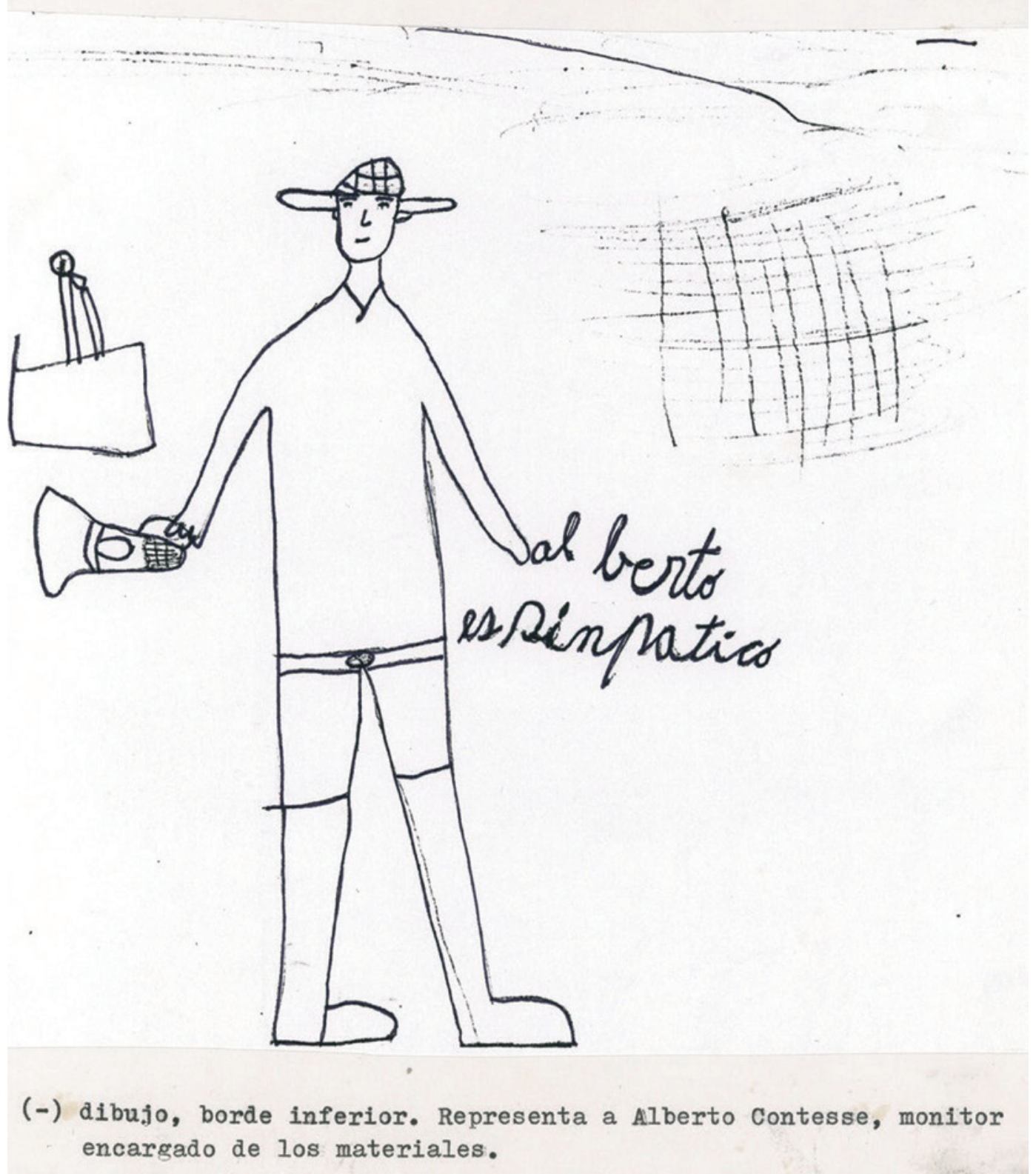

'My view is that film is very good, as well as the people running the workshops. The man who was talking is good' - Workshop participant, aged 11. The drawing represents Alberto Contesse, the instructor responsible for the materials, Pataguas Cerro, Vi Región, 1993

During the second workshop we ran in Pudahuel, a boy stole a box full of chocolate bonbons. At first he started kicking the box around with a friend so that the instructors had to intervene. Members of our team are schooled not to take the bait in situations like these. I approached the boy when he was returning to his table with the box and told him: 'Look, ... have that box of chocolate bonbons and do whatever you want with it, but I don't want to see you again at the workshop. You're eleven and our policy 
is to accept children up to ten years of age. You know you are over the age limit, and, since you are being a nuisance, despite knowing all too well that these snacks are for everybody, you will have to leave the workshop.' The boy grabbed the box and left with his mates. Lucille, an instructor from France who has worked with us for more than a decade, told me: 'It hurts my heart to see this boy leave. Perhaps he took the chocolate bonbons because he didn't have any breakfast.' If we excused this type of behaviour all the time, the project would not be viable. To finish the story, the boy returned ten minutes later with his friends and said: 'Miss, I'm giving you the box back because I'm feeling bad about it.' We shook hands, I gave them their share of bonbons

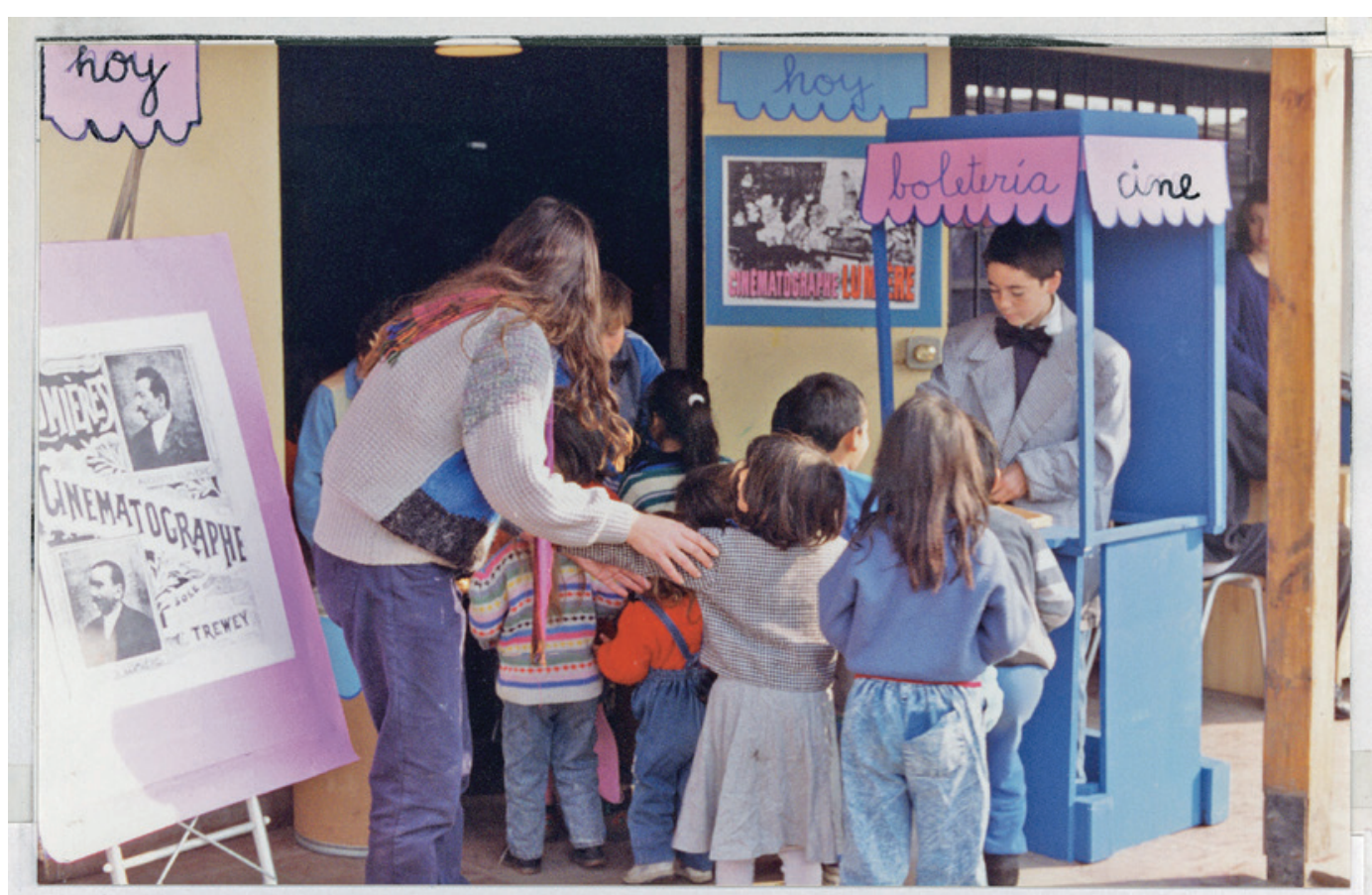

el juego de ir al cine: con todas las agradables formalldades tradicionales

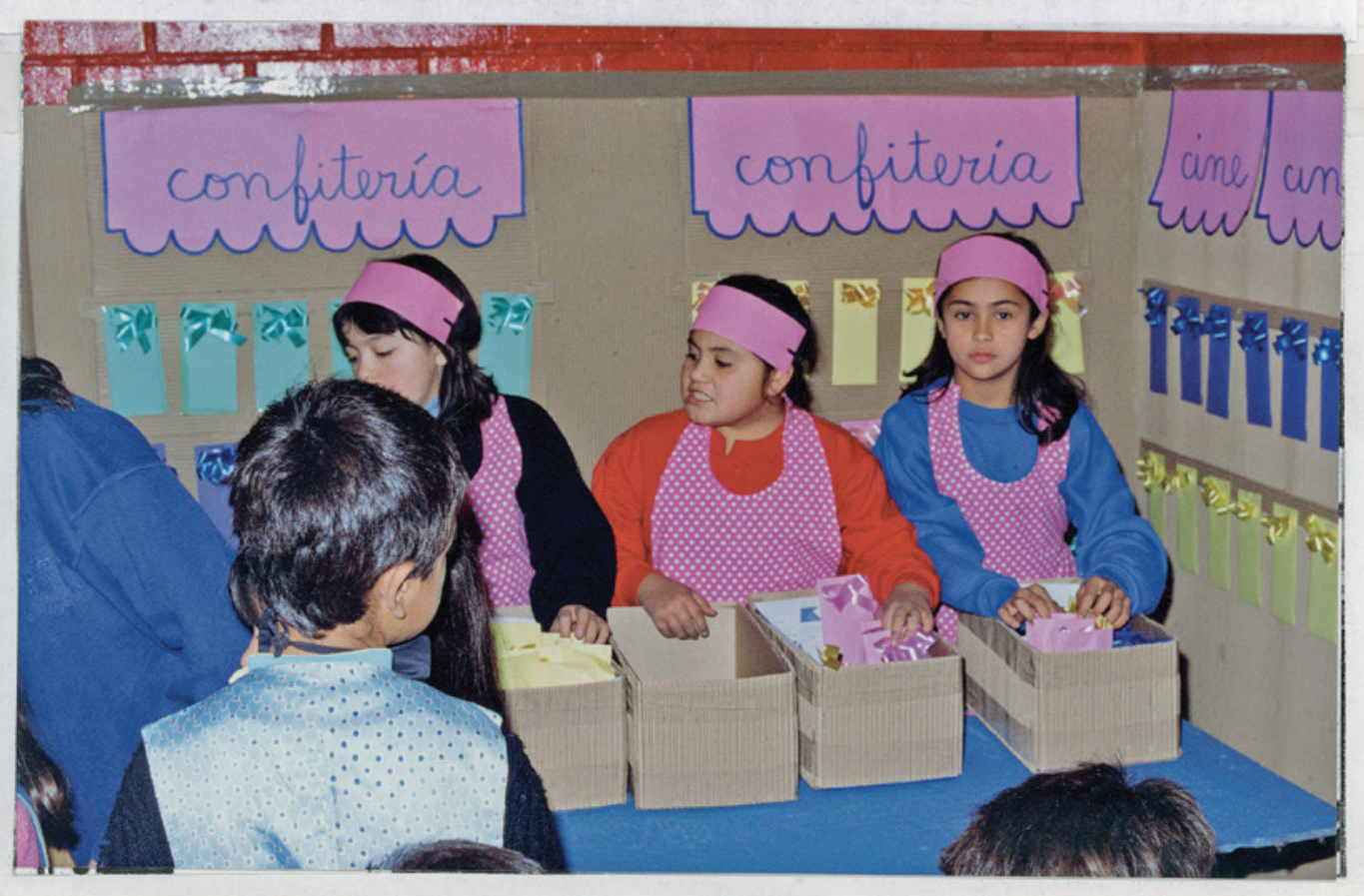

Going to the movies with all the enjoyable traditional conventions. La Chimba, Recoleta, 1994 
and they left. The following Saturday all returned except for the boy who had taken the sweets, perhaps too self-conscious about the damage he had caused. However, he later apologized on the day we all went to the cinema as a group.

Since we do not have our own financial resources and given that the project is aimed at children who could never afford to pay for a film course, we have to apply annually for funding in order to cover costs (such as printing, stationery, props, costumes, folders, food, transport, maintenance, fees and shows). The cost for each workshop is over 6 million Chilean pesos $(£ 6,000)$ and funding has come from a variety of sources throughout our 27-year existence. Embassies, churches, local and national institutions, the Ministry of Education, Fundart (Fondo Nacional del Desarrollo Cultural y las Artes), the Cineteca Nacional (Chilean Film Institute) or the Junta Nacional de Auxilio Escolar y Becas (National School and Scholarship Assistance Council) have enabled the continuity of the programme; smaller donations have also been valuable as they allow us to cover the costs of basic supplies, from food to underclothes, for the children during the winter months. Among the institutions that have been contributing repeatedly, two deserve special mention: the Stiftung für Sozial Benachteiligten Kinder, whose president, Yvonne Müller, has visited us on three separate occasions from her base in Bremen; and the Association d'Amitié France-Chili, championed by Irene Domínguez, who collected funds for us for over a decade from Chilean artists based in Paris.

Once, the commercial attaché for Finland, accompanied by his wife and my friend Flu Volonmaa, arrived in the village where we were running a workshop. They were extremely shocked by the high levels of poverty and very much taken by the enthusiasm of the children. The attaché then informed me that he had to leave to attend a meeting with the leader of the Finnish trade unions.

A few months later, I received a call from a professor at the School of Art at the Universidad Católica, explaining that he had a good relationship with the workers' trade union in the municipality of Rinconada de Los Andes (in the region of Valparaíso). Apparently, the members of the union had seen Cien niños esperando un tren (Ignacio Agüero, 1988) on television and wanted to get in touch with me to explore the possibility of running a workshop in their municipality. I explained that my work as a university lecturer would not allow me to travel back and forth from where I lived to their village but that I would be prepared to run a summer workshop if I stayed in Rinconada for a month. I also queried whether they had any funds at all to run the workshop. Predictably, the answer was no. I did not have any funds either, but I thought of my Finnish contact and called the Finnish embassy, whose advice was to apply for funds in writing. A month later I received a response notifying me that the embassy could contribute $\$ 9,000$ (only $\$ 1,000$ less than I originally requested). That was the beginning of a wonderful workshop. We set up in a shack that the workers used as headquarters and built an annex with two rooms where we stayed. We slept in sleeping bags and managed to build a makeshift bathroom. With the help of parents and the direction of Patricio Evia, an architect and friend of mine who participated in some of our workshops, we built a special room that could be darkened to screen the films. This room was our legacy to the community of Rinconada.

One of my main regrets is not having had the financial means to plan three, four or five consecutive years of workshops, or being able to secure the backing of a business or an institution that could have supported us with a one-off budget of 25 million Chilean pesos to purchase and to preserve wholesale materials. Once I approached the United Nations Children's Fund (UNICEF), but my request was rejected since projects like ours were not a priority for that institution. Bearing in 


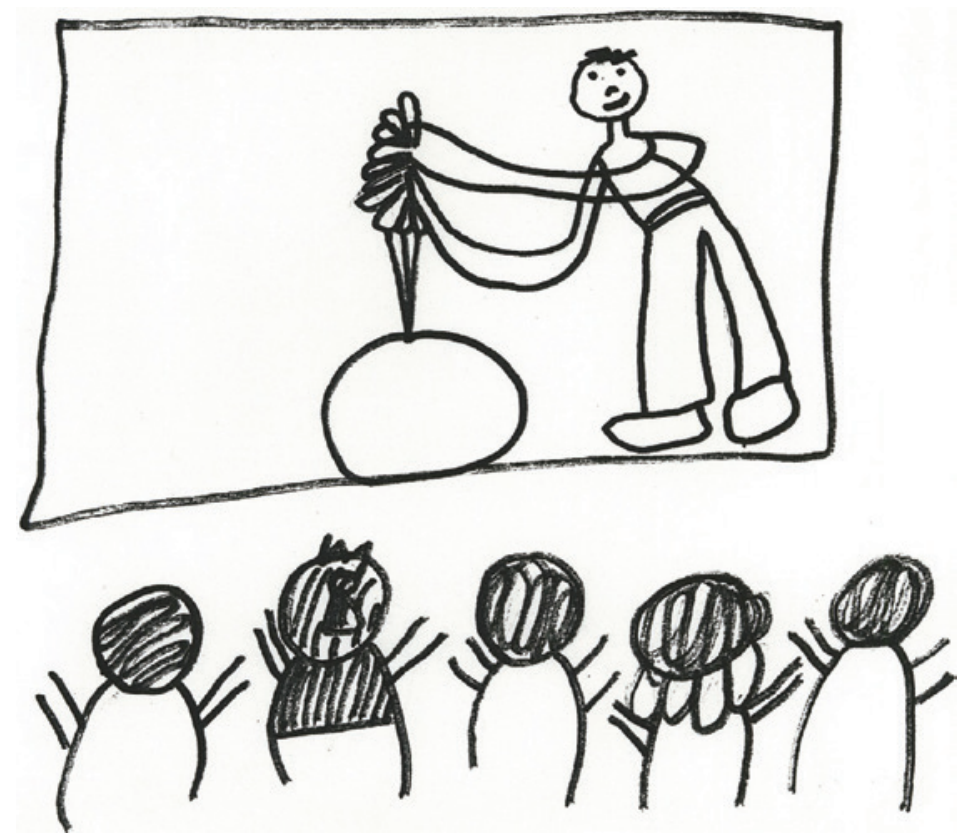

Drawing by workshop participant, aged 6. 'It is a drawing of The Sword in the Stone (Wolfgang Reitherman, 1963), a film that the children watched in a cinema in Santiago de Chile's city centre as part of the session "Today we are going to the movies".'

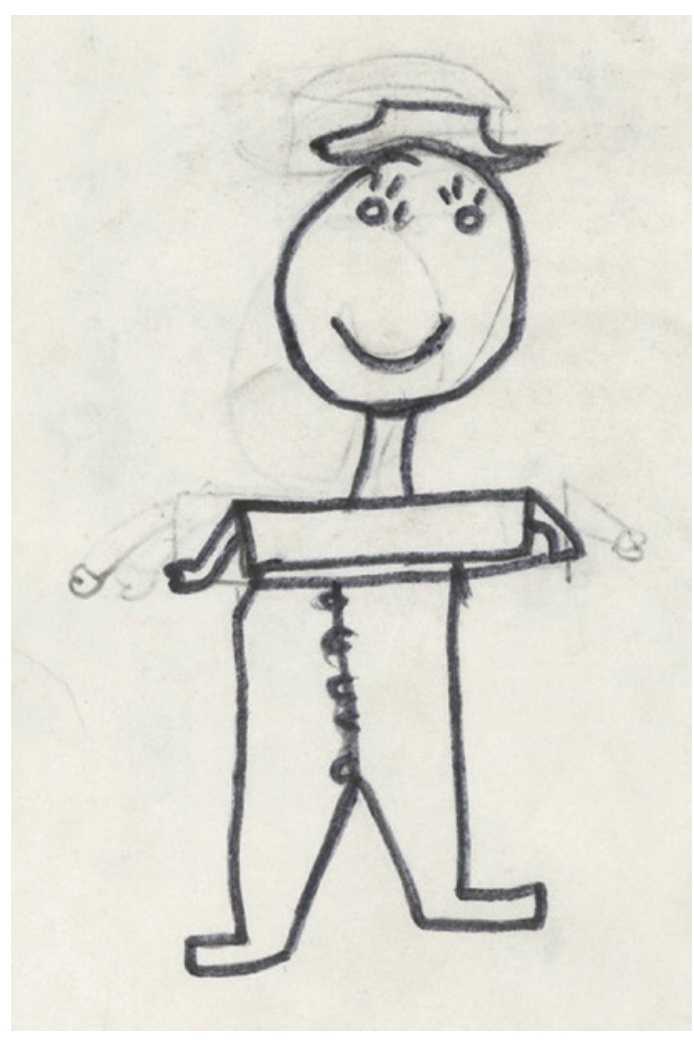

A workshop participant drew this picture of Charlie Chaplin after seeing him in The Pawnshop (1916). From its basic style, one would assume this is a picture of a boy aged 4 or 5 . She used a graphite pencil, refusing coloured markers. Cristo Vencedor, Lo Hermida, 1989 


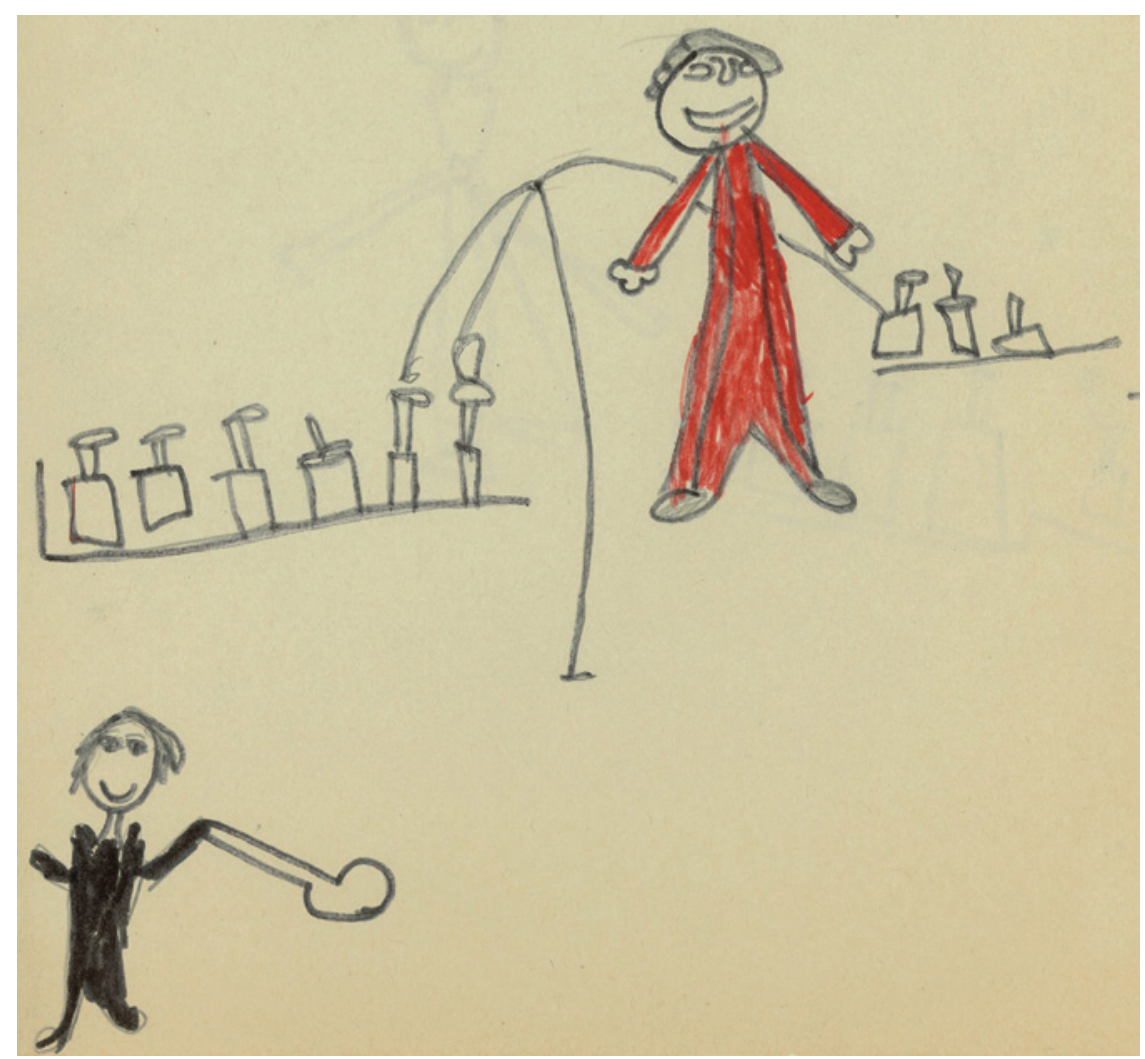

A week later the same girl drew a glass blower, inspired by the documentary by Bert Haanstra (Speaking of Glass, 1958). She made progress in relation to her previous work since she located her character in a context and placed it in relation to the lead character. She coloured both (in red and in black). Cristo Vencedor, Lo Hermida, 1989

mind that the workshops began under the auspices of the Catholic Church, many people suggested that the project should be used to catechize; in other words, to work as a Sunday School. Others proposed that it was the ideal forum to feed participants specific political ideologies. To my mind, both options would have meant personal failure, although I am certain that it would have been easier to obtain funds if I had given in to the pressures of some governmental and non-governmental organizations (NGOs). To a certain extent, the workshop 'lives from hand to mouth'. Like the slum-dwellers we work with, we just buy what we need every year, and every single year we worry whether we will be able to run a new course. As is common in Chile, many projects like these are only possible because of friends and their personal contributions.

My friend Marcial Valiente, who owns a printing shop, is a clear example of a supportive friend, since he always goes out of his way to provide materials we need, such as cardboard discs for the zoetropes; without this type of help, I would spend all my time getting the materials together.

As part of the project, I have also published an accompanying textbook. Each print run costs a million Chilean pesos, but this investment is not worthwhile if the children throw the books on the floor or do not read them at all. It is crucial to decide how to best use the money we have at our disposal.

When I first started these workshops, people had less access to cinema compared to today. However, the predicament of Chile's poorest families has changed less than one might have hoped - certainly, much less than economists' data tends to suggest. 


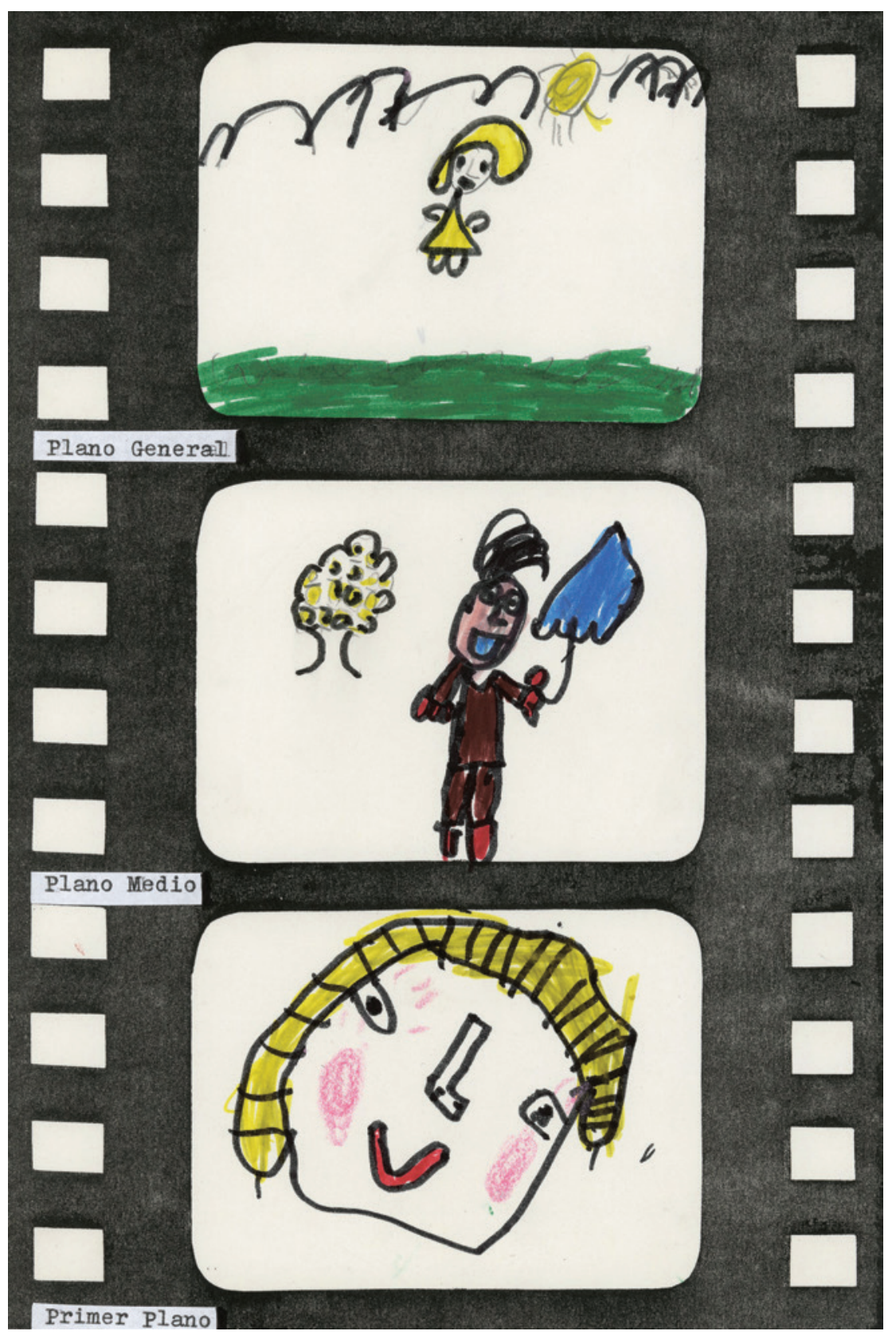

Activity: Now that you have practised using the different frames, try to draw three frames. Workshop participant, aged 5, Chuchunco, 2003

Families do not know what they will have to eat from day to day, how much money the parents will bring home at the end of each day, or whether they will have enough to buy paraffin or medicine for their elderly relatives. Culture is not part of their everyday life. Children often show aggressive behaviours and are not used to sharing, traits characteristic of those who live in environments rife with violence, poverty and lack of affection.

When we visited the village of Lo Sierra in 1986, one could only see rubbish dumps; there were no green areas for children to play in. Despite having a medical centre and a police station, the streets were unpaved. Unemployment, precarious housing and a lack of basic food translated into all types of illnesses. Alcoholism, now often replaced by addiction to drugs such as cocaine, was still a serious problem in 
some families. In these poverty-stricken surroundings, where parents are plugging illegally into power sources in order to be able to light a room or cook a meal, and where children are victims of huge indifference, the workshops were seen as a sign of hope.

A news item featured in the daily La Época in 1986 gives us a sense of the abject poverty in which people in this municipality live: 'We returned to our damp and flooded houses with a kilo of chickpeas and three pieces of cardboard treated with tar,' said one of the inhabitants of Lo Sierra. 'The rain of the last few days ... has worsened the situation even more, in particular the lives of many children who are falling ill.'

We handed out the programme of events to the children of Lo Sierra at the start of the workshop so that they all knew the topics that we were covering each week: thaumatrope, magic roll, the invention of cinema by the Lumière brothers, the difference between documentary and fiction, camera movements or film-going as an event. The only information that was withheld from them - kept as a surprise until the very end - was the name of the film to be screened in each of the sessions. The fact that they knew the topics we were discussing reduced their anxiety and increased their confidence; in other words, the children realized that what we promised was fulfilled, and that our weekly sessions were, first and foremost, about them enjoying the two and a half hours we spent with them.

A total of 204 participants attended the workshop in Lo Sierra: 125 boys and 79 girls. Half of them had never gone to the cinema. Most of them were constantly cold and all the boys carried penknives. When we invited them to disarm, the boys themselves devised a system whereby they would thrust the penknives into a plank of wood by the entrance and would only collect them on their way out.

In Lo Sierra we had some problems, too: once some boys tried to steal the bell of the chapel from the cellar. On another occasion one of the boys arrived with a martial arts weapon that we had to confiscate. Some other anecdotes are worth recounting: for example, the time when a group of boys sold the zoetropes in the local market and asked us to make more because people wanted to buy them. The average attendance at the workshop was around a hundred children, which was acceptable if we take into account family issues, sickness and bad weather. However, there were full houses for the exhibitions as well as for the end-of-course party with the parents, at which we supplied two roasted turkeys and four cakes.

As with many of the other workshops in locations we visited, we struggled with absenteeism in Lo Sierra. Among our strategies to counter this were completing a topic per session and sending notes to absentees' houses, emphasizing that the children were missed. During the sessions we stressed that commitment to work and to working in a group were more important than being good at plastic arts.

The then director of the German Goethe-Institut, Heinz Jürgens, who had already attended the first workshop in Huamachuco (La Libertad), expressed his interest in joining our project in Lo Sierra because a German specialist in children's literature he knew would benefit from learning about our activities. When they joined us and observed the children at work in groups, our visitors asked the children some questions, with Jürgens acting as a translator. The children loved it. At some point during the workshop, somebody knocked on the door and the whole room went silent. It was an 11-year-old boy who looked a bit embarrassed about being late. I introduced him to our guests and told him they had come all the way from Germany, at which point he raised his arm vigorously and cried 'Heil Hitler!' Our guests burst into laughter.

Jürgens returned to our workshops on other occasions with other visitors. He would call and confirm date, time and location. One day he came with Horst Schäfer, 
who had been working in the field of children's cinema and who contributed regularly to an important German publication devoted to the topic, Deutscher Kinderfilm. Schäfer was very impressed with the project but also shocked by the poverty of participants. Shortly after his visit, we received a copy of Deutscher Kinderfilm with a lead article on the workshop entitled 'Laurel and Hardy, Herzog and the children of Lo Sierra in an extraordinary project of cinema for children in Chile'.

Eight years later, in 1994, we went to La Chimba at the request of the municipality of Recoleta, whose Department of Culture was led by Raquel Barros and the local cultural representative. Although during colonial times all the territory north of the river Mapocho was known as La Chimba, in 1994 it corresponded to a small village in which there was no school, no medical centre and no chapel. A total of 288 families, plus wider relatives, lived in La Chimba, with a minimum of 6 people per household.

\section{TALLLTR TY CI CIE"

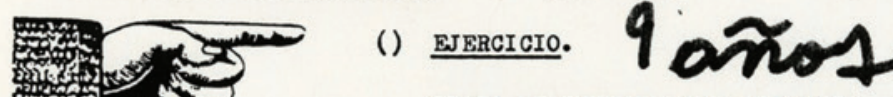 TRATA DE INVENTAR UNA HISTORIA, ESCRIBIENDOLA Y DIBUJANDOLA EN TRES CUADROS.}

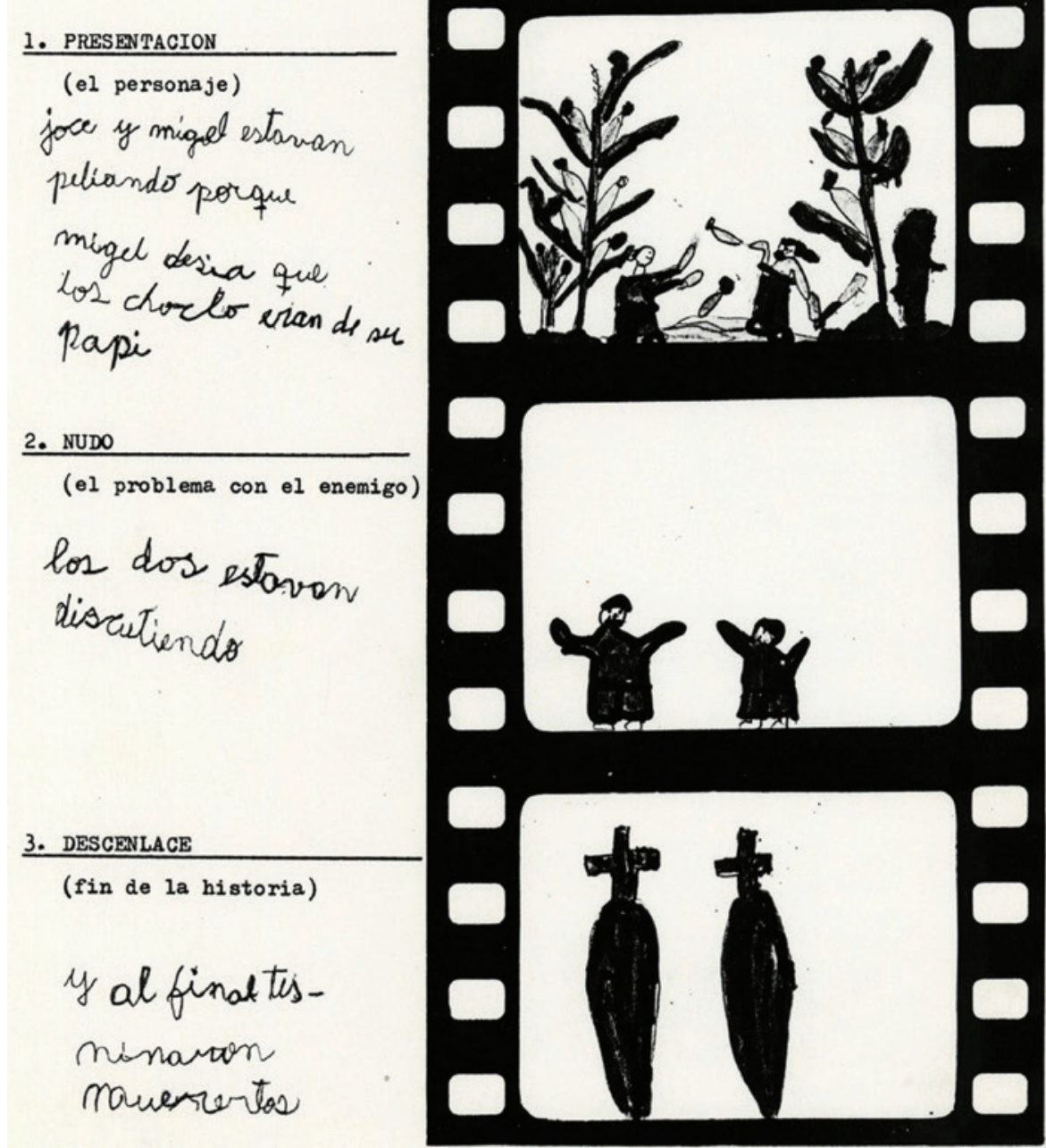

Storyboard exercises by workshop participants, aged 9 and 11. Pataguas Cerro, VI Región, 1993 


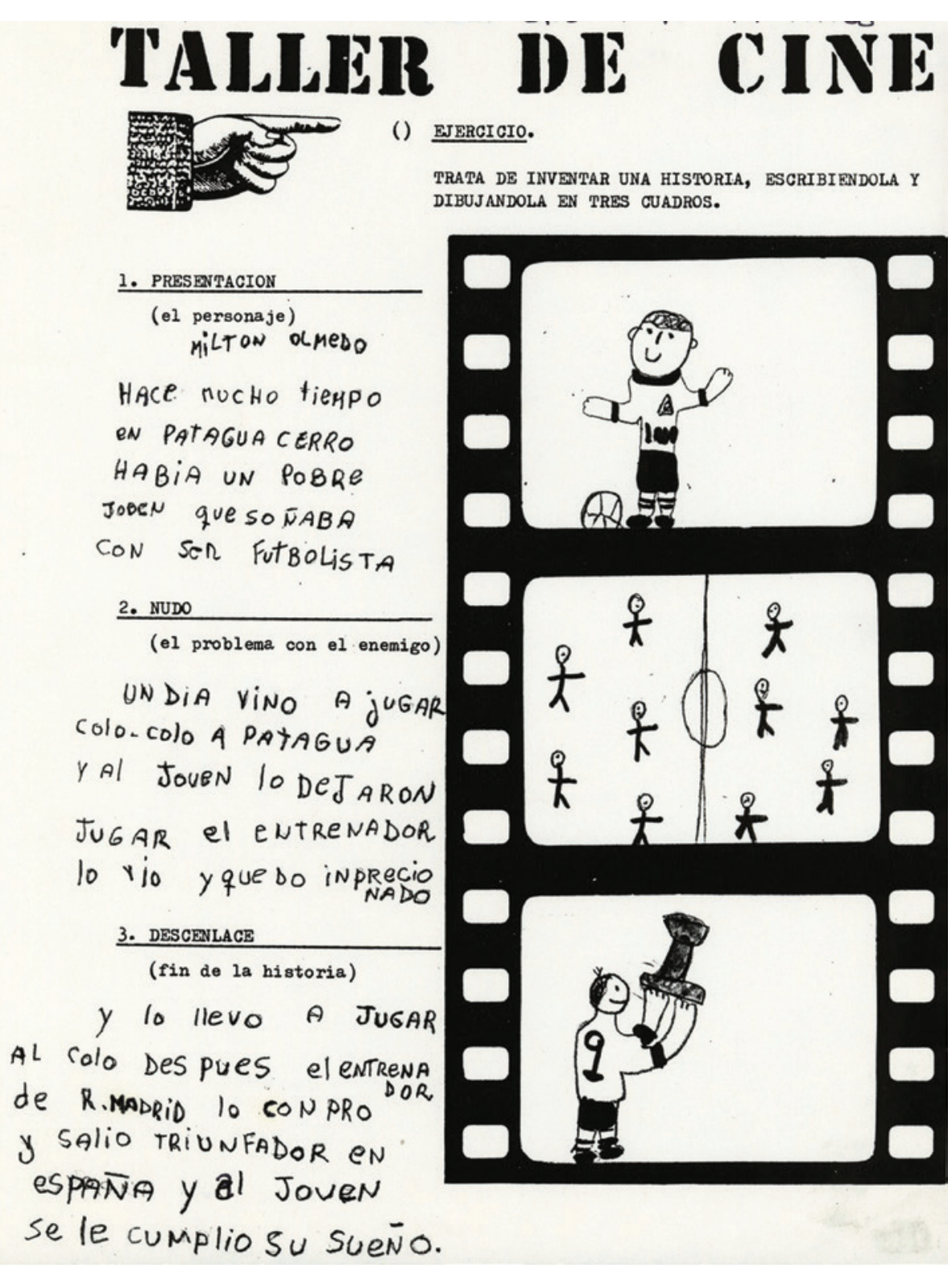

Storyboard exercises by workshop participants, aged 9 and 11. Pataguas Cerro, VI Region, 1993

The social deterioration in La Chimba was serious and visible: drunks and drug addicts populated the streets. Since the Neighbourhood Association Number 10 was the only community site in the region, the hall we used for the workshops was also the base for courses in jam-making and dressmaking, as well as for two other workshops, one for drug addicts and another for the prevention of teenage pregnancies. Given the relatively small size of the hall in relation to our 202 participants, we decided to use it for the projections and the patio for all practical activities, which required us to fence it in so that children could concentrate and not be interrupted by idle passers-by.

Due to the lack of a school in La Chimba, children attended schools in other areas of the municipality, namely Escuela Manuel Rodríguez, Escuela Abdón Cifuentes or Escuela Santo Domingo. Their deprivation was made clear by the fact that 32 out of the 202 children did not know the name of their school and that children as old as 10 commonly made mistakes when writing their own surnames. In order to account 


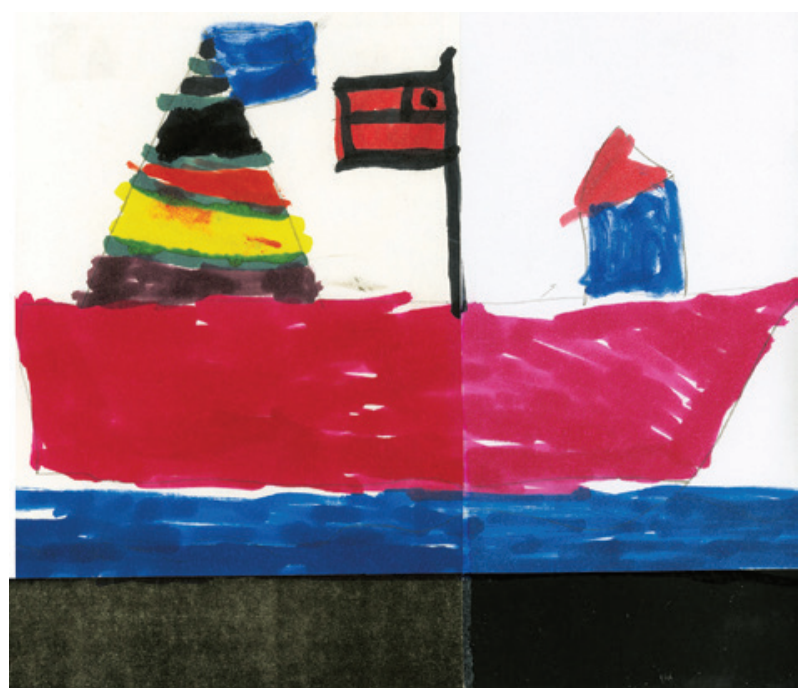

When asked as a group to draw a film they all chose (democratically) the sea as a theme. Each one of the children was responsible for a still. The image here shows a section drawn by a 6-year-old workshop participant. Ciudad del Niño, Castro, 2002

Y así, estimuladas, las niñitas dibujaron el personaje de Caperucita Roja el día que iban a "filmar" el cuento::
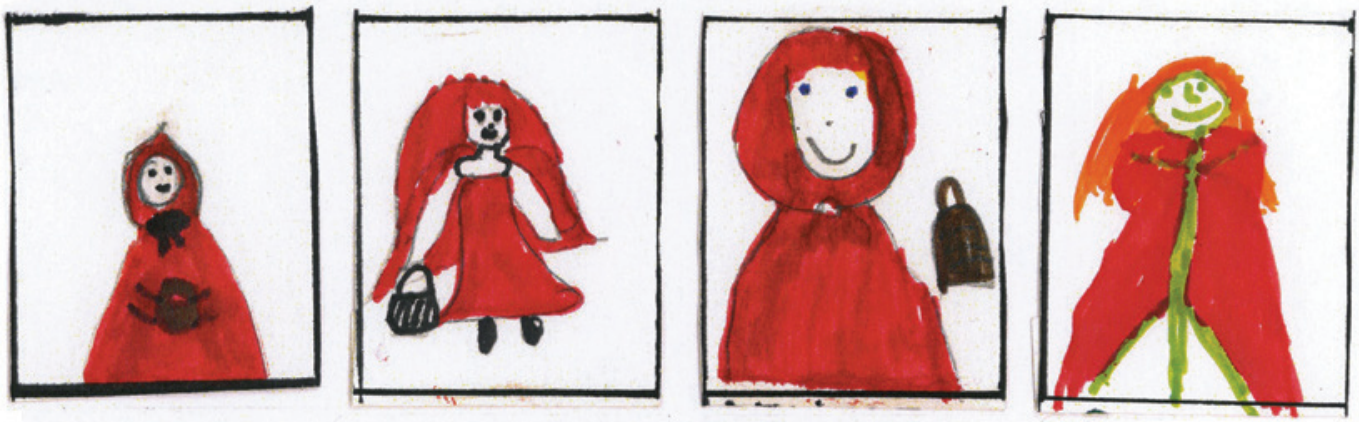

Extremely excited, the girls drew the character of Red Riding Hood the same day they were going to 'film' the tale. Drawn by workshop participants aged 9 and 11 . Cardenal Silva Henríquez, Castro Alto, 2006

for the lack of a father in their home, many explanations (in writing) tended to be very similar: 'my dad left' or 'my mum kicked my dad out 'cause he was a drunkard'. But the most evident issue was their lack of concentration, for they were constantly fidgeting, squabbling, talking or trying to jump over the gate to go and do something else. There were also thefts as soon as we started, whether it was food or the materials that our instructors Bernardita Puga and Alberto Contesse had laid in boxes. Unaware of the unhappiness their actions caused, many of them would raise their arms and ask to be searched, safe in the knowledge that the booty had already been passed on.

These observations are not intended to stigmatize these children, far from it. They reflect our experiences in the various workshops we run. The aggressive behaviour of the older children contrasts with the shyness of the younger children, but it is also 

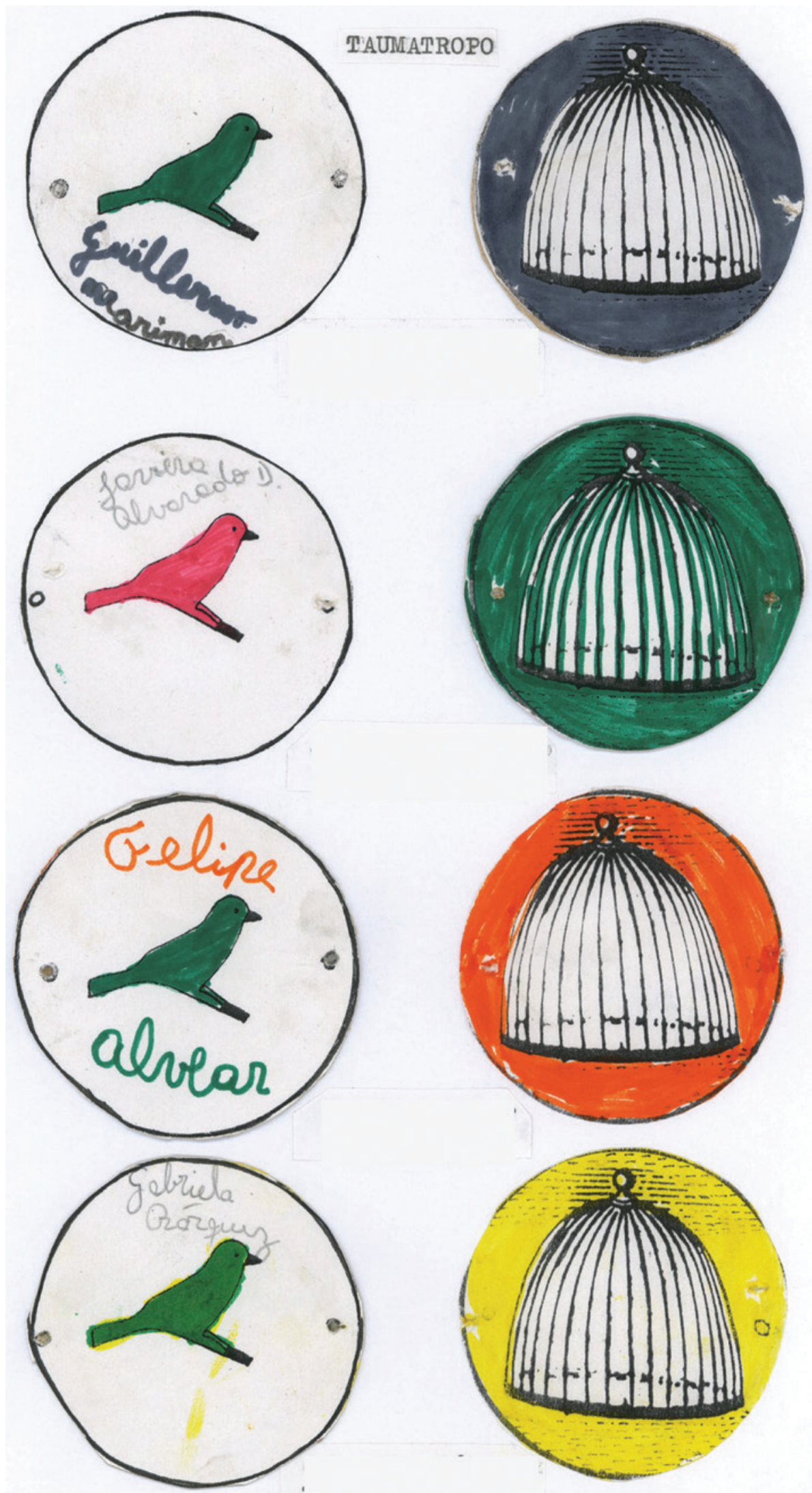

Thaumatropes made by workshop participants aged 7 and 11. Cardenal Silva Henríquez, Castro Alto, 2006 


\section{TALLER DE CINE PARA NIÑOS}

\section{querido Gary:}

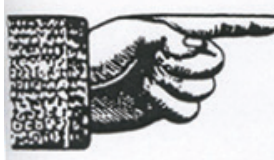

TE ESTAMOS ECHANDO DE MENOS EN BL TALLER DE CINE PARA NIÑOS DE LA UNIDAD VRCINAL NQ 10.

QUEREMOS AVISARTE QUE NOS GUSTARIA MUCHO QUE VOLVIE RAS OTRA VEZ.

EL HORARIO BS COMO SIRMPRE: TODOS LOS SABADOS DE $10 \mathrm{~A}$ 12 HORAS, MMPRZANDO CON UN RICO DESAYUNO.

TE SALUDA CARIÑOSAMENTE

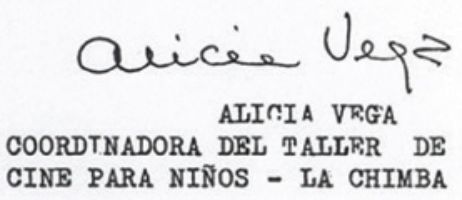

SANTIAGO, 25 DE JUNIO DE 1994.

Letter from Alicia Vega to workshop participant. The text reads: 'Dear Gary, We are missing you in the Cinema Workshop for children at the Neighbourhood Association Number 10. We are writing to let you know that we would like you to join us again. Our timetable is as usual on Saturdays from 10.00 to 12.00 , kick-started with a delicious breakfast. Lots of love, Alicia Vega, Coordinator of the Taller de Cine para Niños, La Chimba Santiago, 25 June 1994'

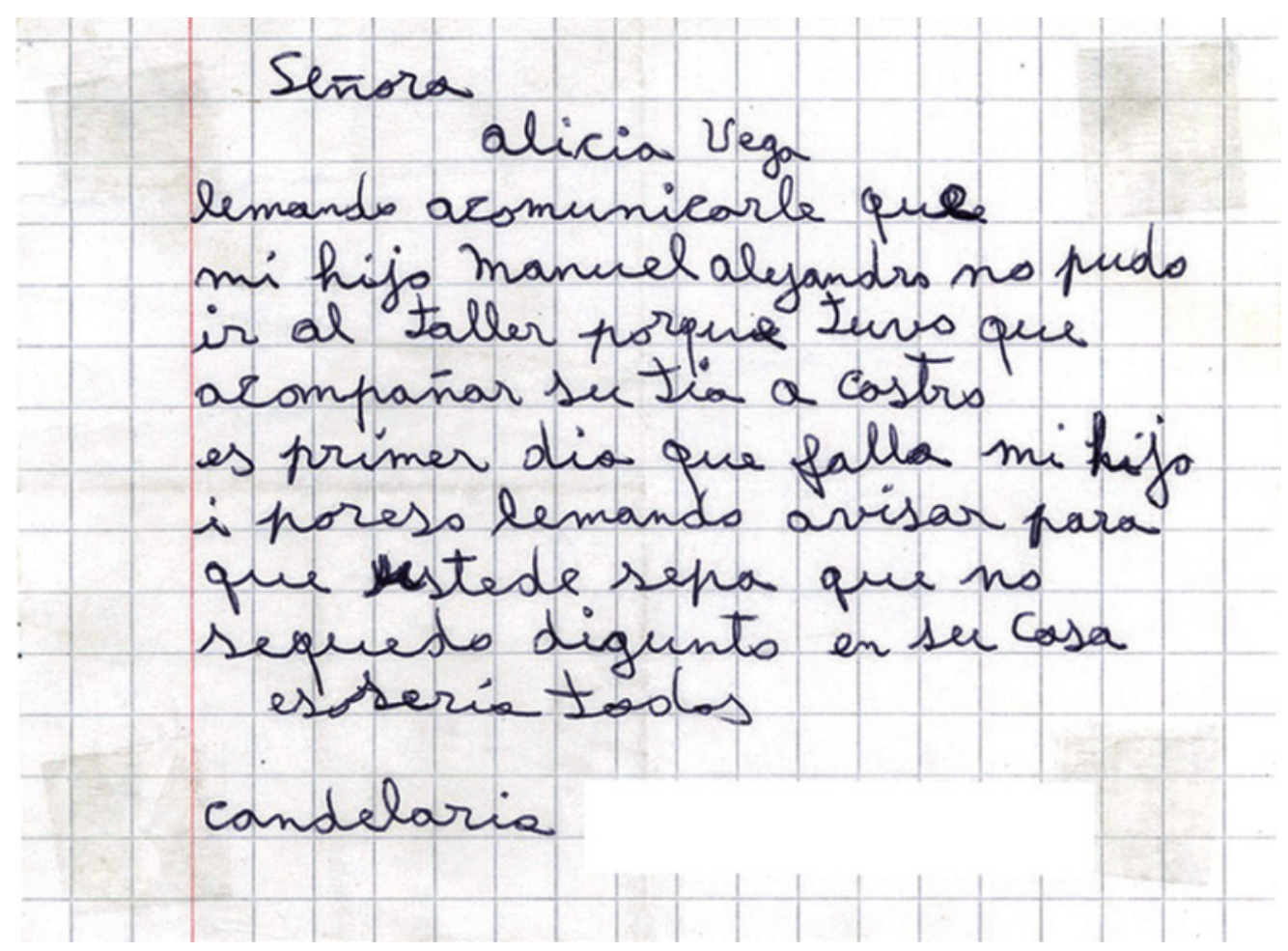

Letter from parent of workshop participant. The text reads: 'Dear Mrs Alicia Vega, I am writing to let you know that my son Manuel Alejandro could not go to the workshop because he had to accompany his aunt to Castro. This is the first time he has not attended and I wanted to let you know that he was not skipping the session to stay at home. Best wishes.' Queilén, 2000 


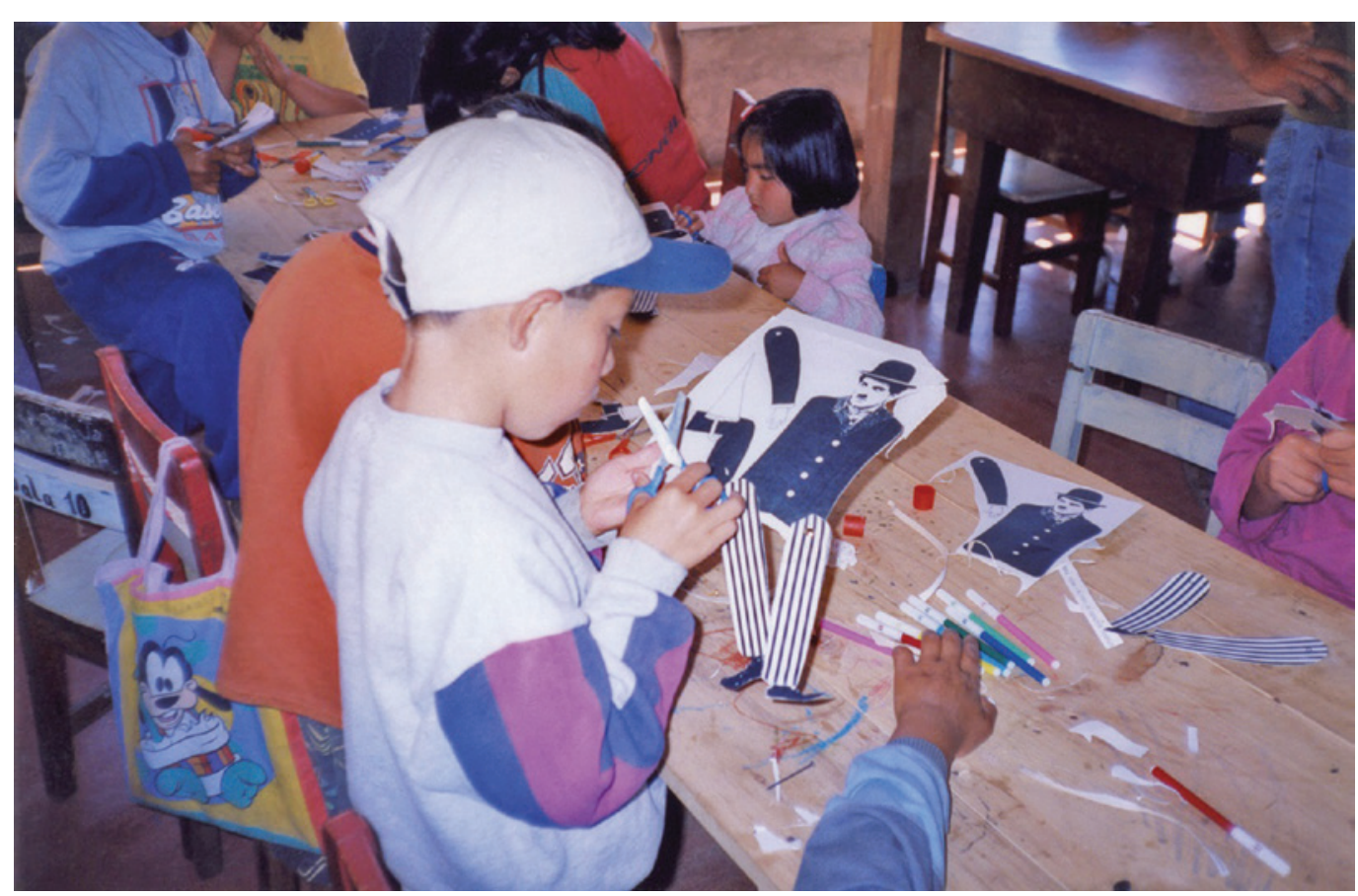

Workshop participant. Ancud, 1999

very stimulating to observe how the methods we use in the workshop have a positive effect on all of their behaviour, bringing about change in the group as a whole. The children soon realize they have more fun if they apply themselves to the tasks using the materials we make available for them. As soon as those 'negative' leaders start to enjoy the workshop, they get closer to the instructors and, in turn, their self-esteem grows. At times, the achievements of the workshops need to be considered in relation to the aspects I have outlined above and in relation to the children's recognition of a communal space as theirs. For us, a measure of the success of a project was to move from the difficult opening sessions where colleagues would be sworn at and threatened with penknives to the stage where we were asked to repeat the workshop the following year. At this juncture of my account of the Taller de Cine, I should explain the reason why the workshop takes place in a different location each year. It goes without saying this is not an arbitrary decision. The seven-month workshop in urban areas - and the one-month-long workshop when we travel during the holiday period to a region like Los Lagos and towns such as Puerto Octay, Ancud or Quellón - arises from our desire to embark upon a community project that has a beginning, a middle and an end, like any film. Each participant, therefore, whether a child or an adult, knows which stage of the process they are contributing to, and by the end of the experience all participants, if they have truly committed to the project, have a sense of completion.

As far as the film programming is concerned, some films have travelled with us from the outset because they are classics in the history of cinema. I am referring here to films such as La Sortie de l'usine Lumière à Lyon (Workers Leaving the Lumière Factory, Louis Lumière, 1895), L'Arrivée d'un train à la Ciotat (The Arrival of a Train, Auguste Lumière and Louis Lumière, 1896) and Repas de bébé (Baby's Dinner, Louis Lumière, 1895) by the Lumière brothers; The Tramp (1915), The Adventurer (1917) and The Kid (1921) by Charlie Chaplin; Music Land (1935) and Home Defense (1943) by Walt Disney; and Le Ballon Rouge (The Red Balloon, 1956) by Albert Lamorisse. Other films - like 

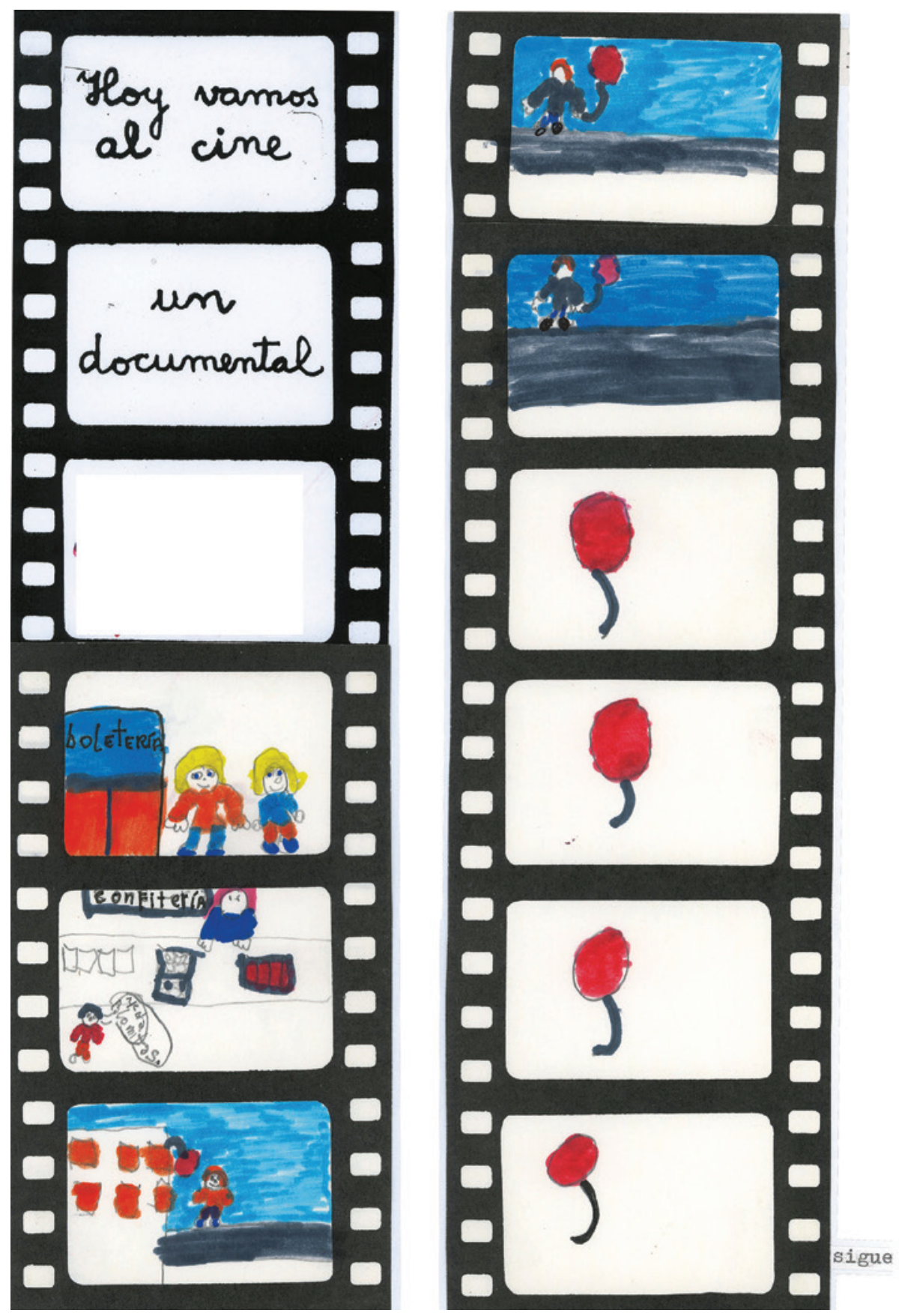

A storyboard exercise. Cardenal Silva Henriquez, Castro Alto, 2006

the Chilean short documentaries El mineral El Teniente (1919) about a copper mining town by Salvador Giambastiani and Entre ponerle y no ponerle (To Pour a Drink or Not; 1971) about the problem of alcoholism by Héctor Ríos - respond to the local realities of Chile. In addition, one of our criteria is to show a diversity of films, so we include films from Canada, France, the United Kingdom, the Netherlands, Germany and the former Yugoslavia. Besides our own film programming, the children also go to see a film on general release, what we have labelled 'Hoy vamos al cine' ('Today we are going to the movies'). During the workshops, films are projected in $16 \mathrm{~mm}$ format and shorts and clips are privileged over long feature films due to time constraints as well as the children's attention span. We use six projectors: two are my own and four 
are donations from Chilean plastic artist Fernando Krahn, Chilean academic Pedro Caraball, the US embassy and the German Goethe-Institut.

Films are screened according to the topics in the programme: some examples illustrate the documentary genre well, others are valuable for explaining editing, composition of shots, the history of animation and so on. It is natural, therefore, that we begin with the Lumière brothers to introduce children to the origins of cinema. They view the six films the Lumières made and they usually ask the most unexpected yet sharp - questions, questions that not even my university students raise.

They want to know who Louis and Auguste were, whether they owned the factory shown on the screen, why the films lasted only a minute or why they were silent. These questions give us the chance to start explaining that neither colour nor sound existed at that point, or that Auguste was the one appearing on-screen because Louis was more technologically savvy and was therefore the one handling the camera.

By providing answers to their questions, you can see your influence over the children increasing gradually, and they, in turn, start enjoying their time as they familiarize themselves with optical instruments, whether this is through touching them, pressing them, drawing them or showing them to others.

Like literature, cinema gives us the opportunity to go beyond our daily lives, to see the world through the eyes of a character, to experience emotions we lack in our lives. Great directors invite viewers to understand their characters, even to identify with them, but never to judge them.

Identification is at work more naturally, of course, if there is an affinity with the experience that is being narrated. In fact, during our workshops there has always been a special affinity with the Chilean black-and-white short documentary Entre ponerle y no ponerle, in which Héctor Ríos shows the terrible effects of alcoholism. 'It is bad to drink a lot. It is very harmful,' wrote a 7-year-old girl who attended the workshop in Pataguas Cerro, District Six, in 1993. 'He faints. He falls. He gets annoyed. He throws up. They take him to prison. He has no food at all. He does bad things. He's taken to hospital. The end,' wrote an 8-year-old girl.

Another film that is popular with the children is Crin Blanc/White Mane (Albert Lamorisse, 1953), where the male participants identify with the boy Folco, the main protagonist, who owns a wild horse wanted by four ranchers whose plan is to sell it. The boy flees, and he is chased, until he rides into the sea with his horse in the most cruel of endings.

Ignacio Agüero is amused when he recalls that, while filming his Cien niños esperando un tren/One Hundred Children Waiting for a Train (1988), he watched the very same films that he viewed as a student at the EAC (Escuela de Artes de la Comunicación). Although we may talk about these films in a different way, both contexts underline the importance of an artist like Chaplin for film language, since during a period in which film expression was shaped by fast editing, Chaplin, who was an outstanding actor, put the emphasis on physical acting. Chaplin pioneered the sequence shot to give the impression that he could make those moves in real life. I have been very impressed with how children can discern where a shot ends or when a particular effect has been used in order to change the temporal construction of a narrative. There is a scene in Chaplin's The Kid where the boy does not know that he is with his mother and the mother does not realize that the boy is her son. They both look at each other, and there is a medium long shot whereby, through the use of the depth of field, the viewer sees the mother leaving the frame while the boy remains in the background, sitting in the house. And yet they are both drawn to each other. A child in the darkness of our film venue 

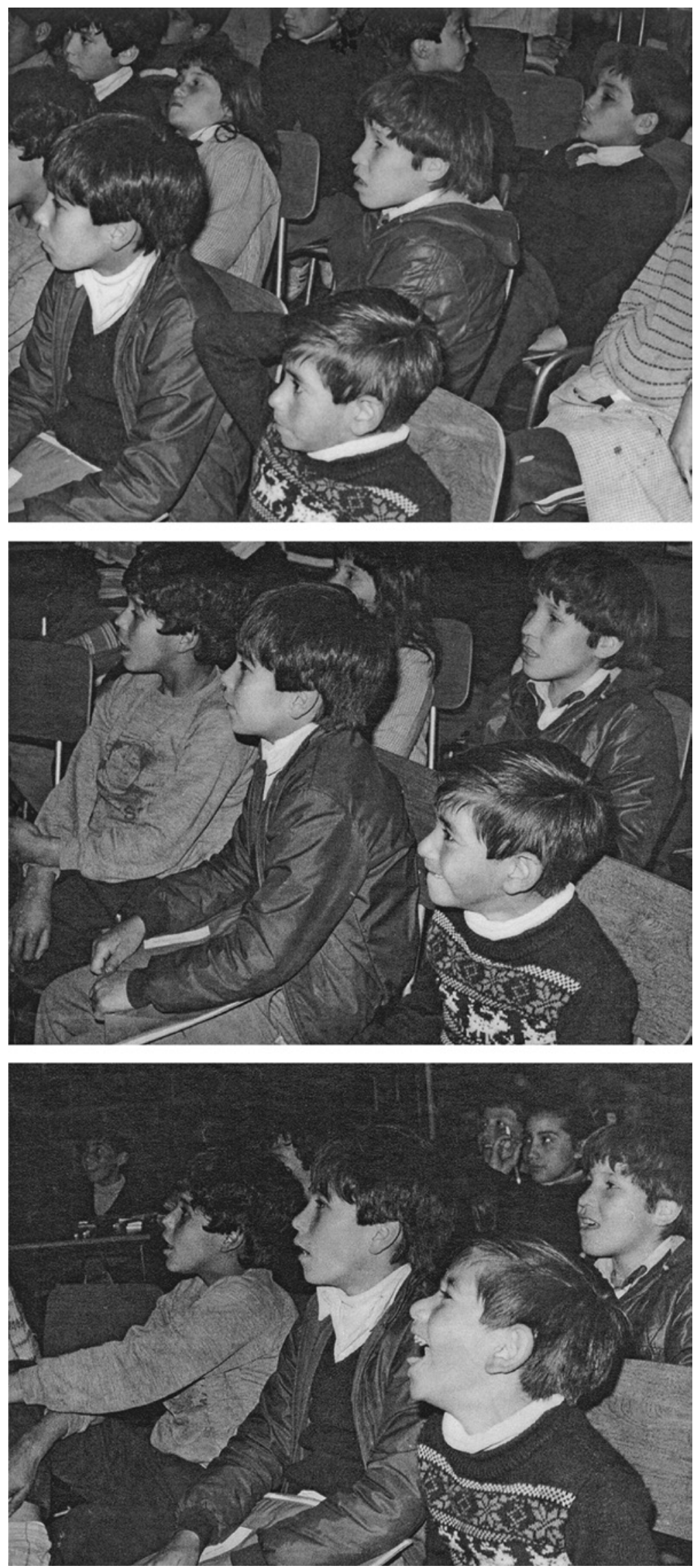

A film strip of the parish Jesús Carpintero, Huamachuco, 1985 


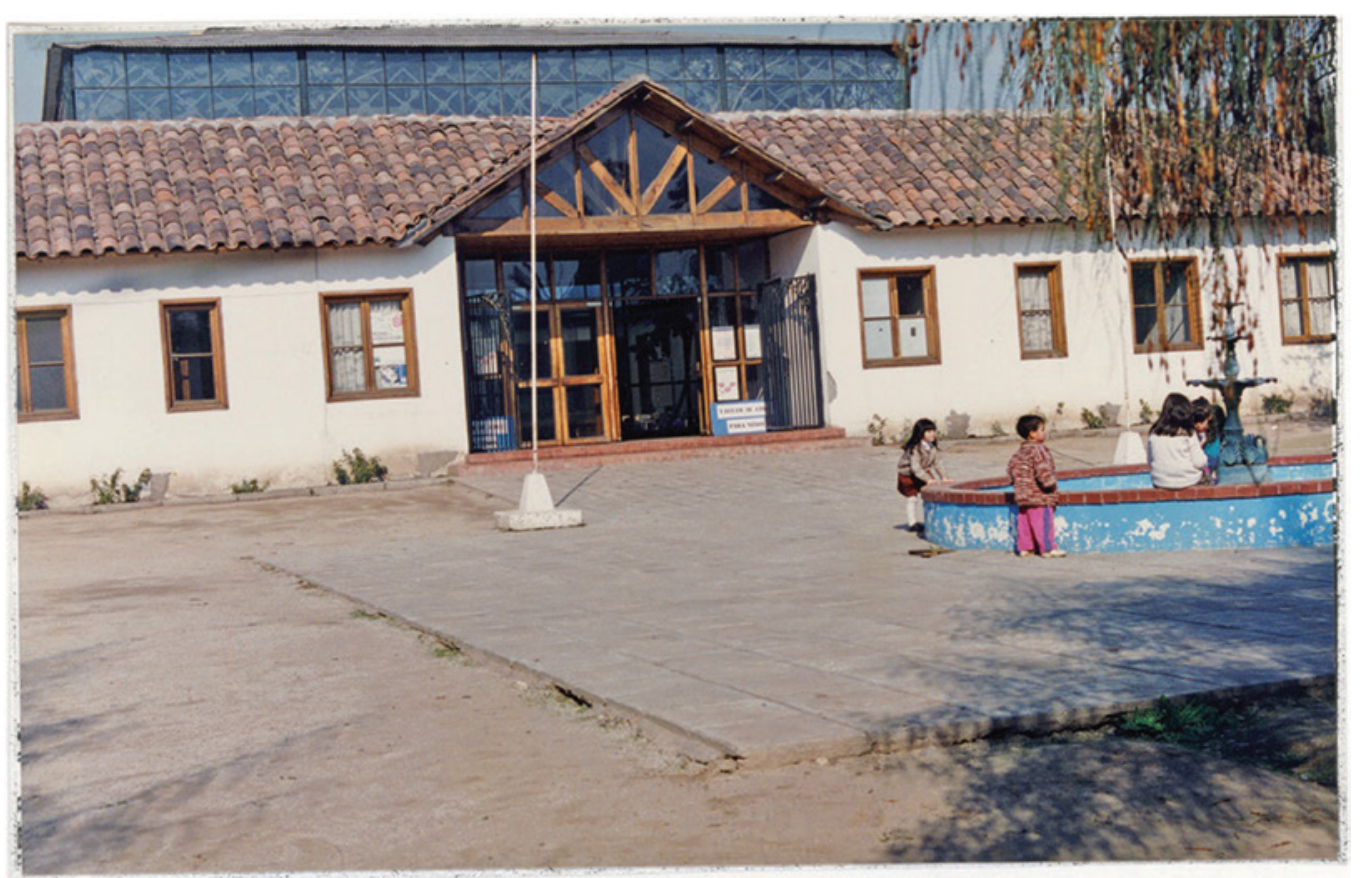

el antiguo invernadero; al interior: estructura metálica y cúpula de vidrio.

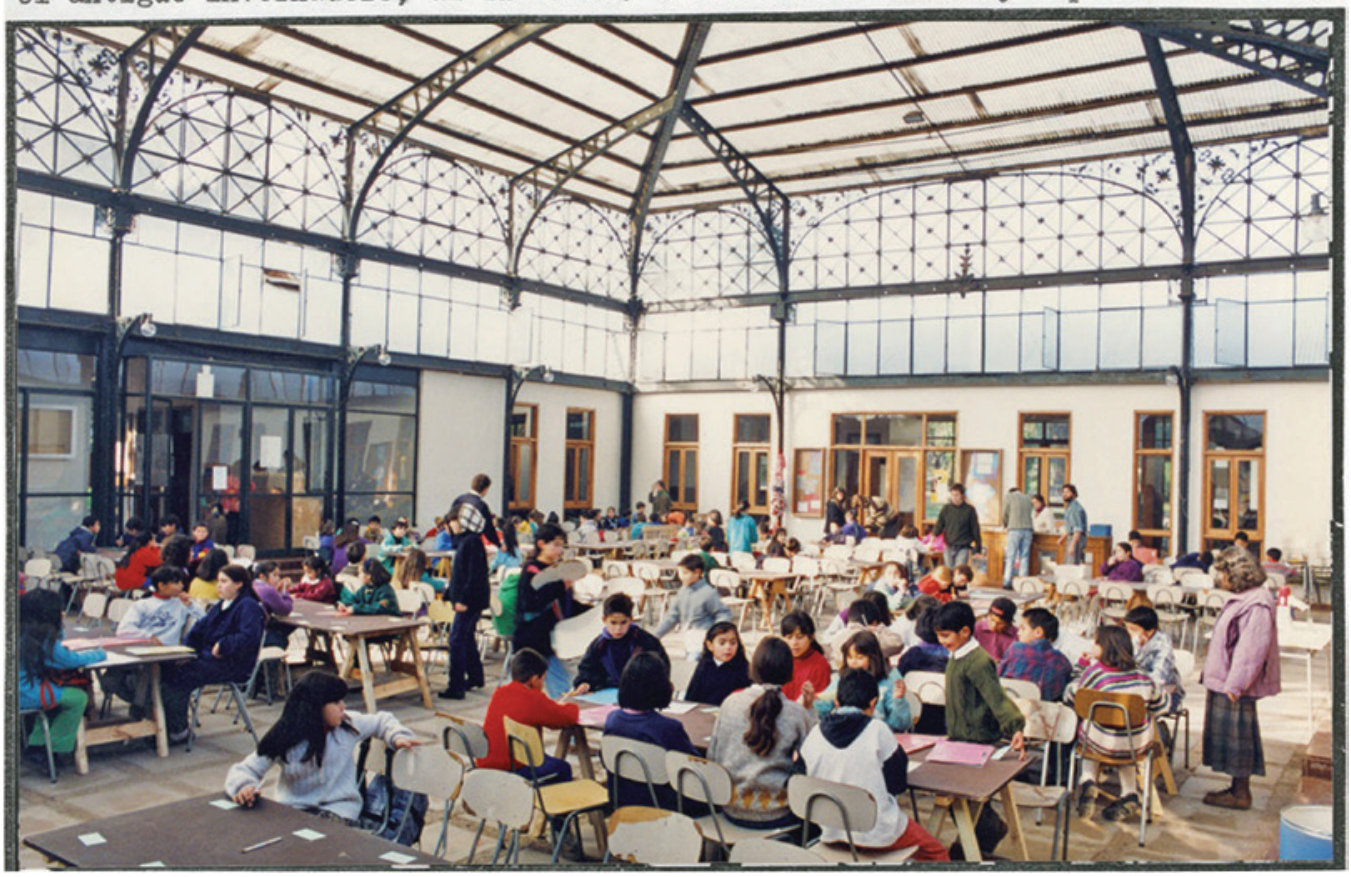

An old greenhouse is repurposed as a workshop space. Pudahuel, Santiago Province, 1995

exclaimed unexpectedly 'Blood is thicker than water.' Chaplin himself would have been moved by this reaction.

The Gospel According to St Matthew (Pier Paolo Pasolini, 1964) was screened in the Ciudad del Niño workshop in 1996, despite being a long film. The gift of Pasolini is how he introduces us to the characters: the spectator 'guesses' who José, María and Judas are before their names are mentioned. Suddenly, a 2-year-old child appears on the screen and the children in the workshop start cheering: they clearly recognize him. I knew that Pasolini had had some problems while making the film. He lacked an actor 

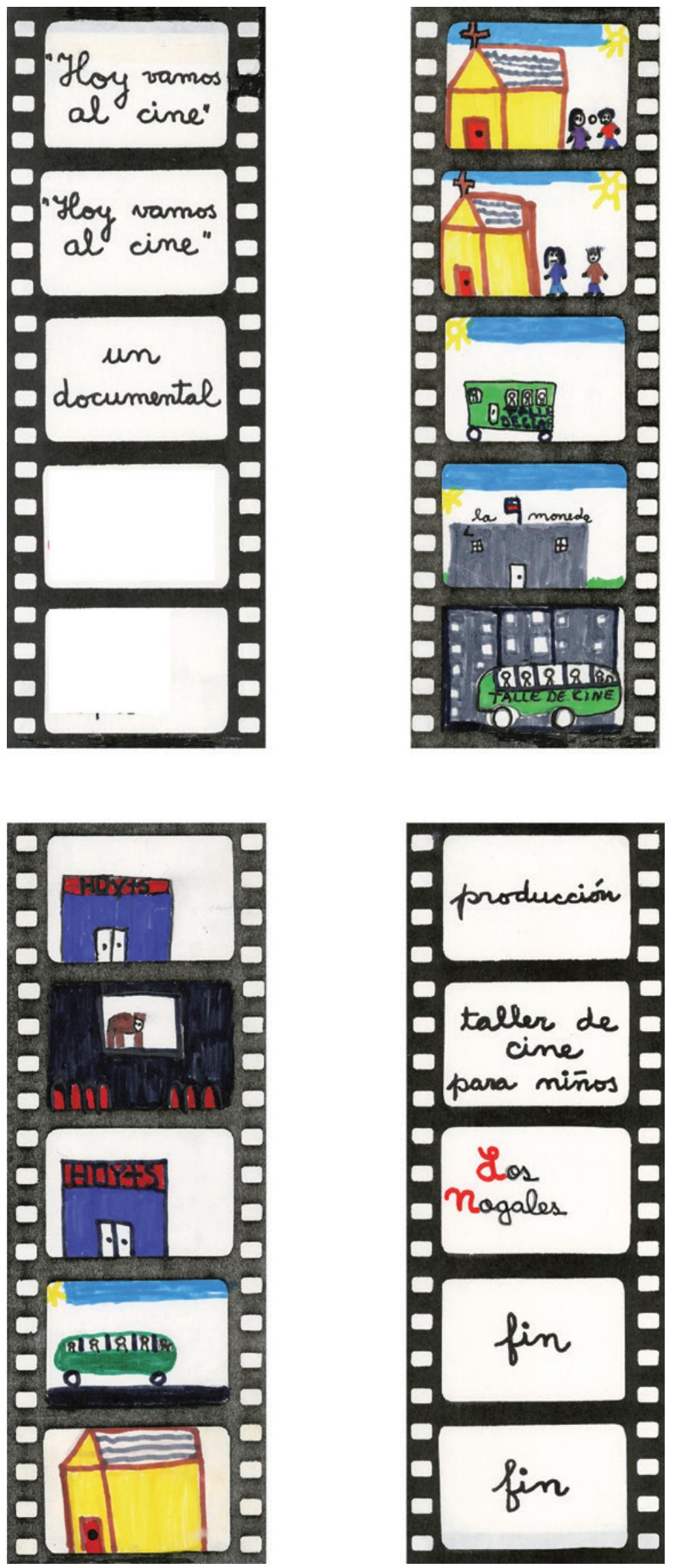

Parish of Santa Cruz de Los Nogales, 2009 
to play the role of Christ. One day a Spanish student, who was working on a thesis on Pasolini's cinema, turned up at his office. Pasolini recalled that, as soon as this young man walked through the door, his Christ had arrived. The director offered Enrique Irazoqui the role, which he accepted even though he had never planned to become an actor.

As I have already observed in this piece, shorts and clips are favoured over feature films, due to time constraints and the participants' inability to concentrate for a long period of time. With The Gospel According to St Matthew we always screened the first reel so that children could grasp the length of a sequence. This proved almost impossible in the workshop at Ciudad del Niño where the audience stood in revolt shouting 'No! No! No! We want to see when he is killed.' They calmed down when we promised to show the full film the following week.

Children know their stories and they are mentally strong. The Ciudad del Niño (City of the Child) is a large orphanage founded in 1943. Our arrival, which was possible thanks to the support of Fundart and the personal efforts of social worker Martha Baudet, coincided with the 100th anniversary of the creation of the San Miguel commune located in Santiago Province. It was certainly one of the most challenging workshops we have ever run: the 636 children sheltered there had been interned there by the justice system. Abandonment by their parents, sexual abuse, poverty, alcohol and drugs, parents in prison had been part of their lives before entering the walls of the orphanage. Given the low self-esteem of these children, the workshop focused mainly on challenging these feelings by stimulating their artistic creativity as well as a sense of freedom. Freedom was unknown to them since any activity in the orphanage is highly regulated: there are strict timetables in place for all daily routines.

The sports hall was the only space where we could fit all the children, but in order to be able to run the workshop in safe and healthy conditions we had to undertake some basic repairs such as fixing the electrics, covering 40 large broken windows and cleaning a room littered with junk and rodent droppings. It took our team weeks to make the hall a suitable area in which to work.

The Taller de Cine at Ciudad del Niño ran between 17 August and 24 December 1996, closing with a party on Christmas Eve.

Although we had planned to welcome all the internees (that is, 636), only 524 were involved in the project. The older girls did not want to watch films, which, in their own words, were 'as old as the hills', and preferred to sunbathe in the playground. Unlike other workshops where we distributed folders and bags with materials, we couldn't do the same at Ciudad del Niño since in institutions like these there is no privacy. Theft is normal despite the existence of individual lockers, which had been vandalized in any case.

In contrast to many other workshops in which a high percentage of children had never been to the cinema, numerous participants in Ciudad del Niño had already been to see films. There is a very simple explanation to account for this. The Board of Directors at Ciudad del Niño had accepted, over the years, invitations from film distributors, as well as from a number of businesses (beverages, confectionery), who needed children to test their products. However, treating the children in such a way (that is, as mere product-testers) disregards the fact that they are in need of affection and feel emotion.

I still recall how the children ran around the hall, clambered onto the stage, pulled the screen, walked on the tables and stole materials during the first month. As soon as the lights were turned off for the screenings, one could hear the swearing loud and clear. Once they left the hall, the chaos caused was not dissimilar from that depicted in The 


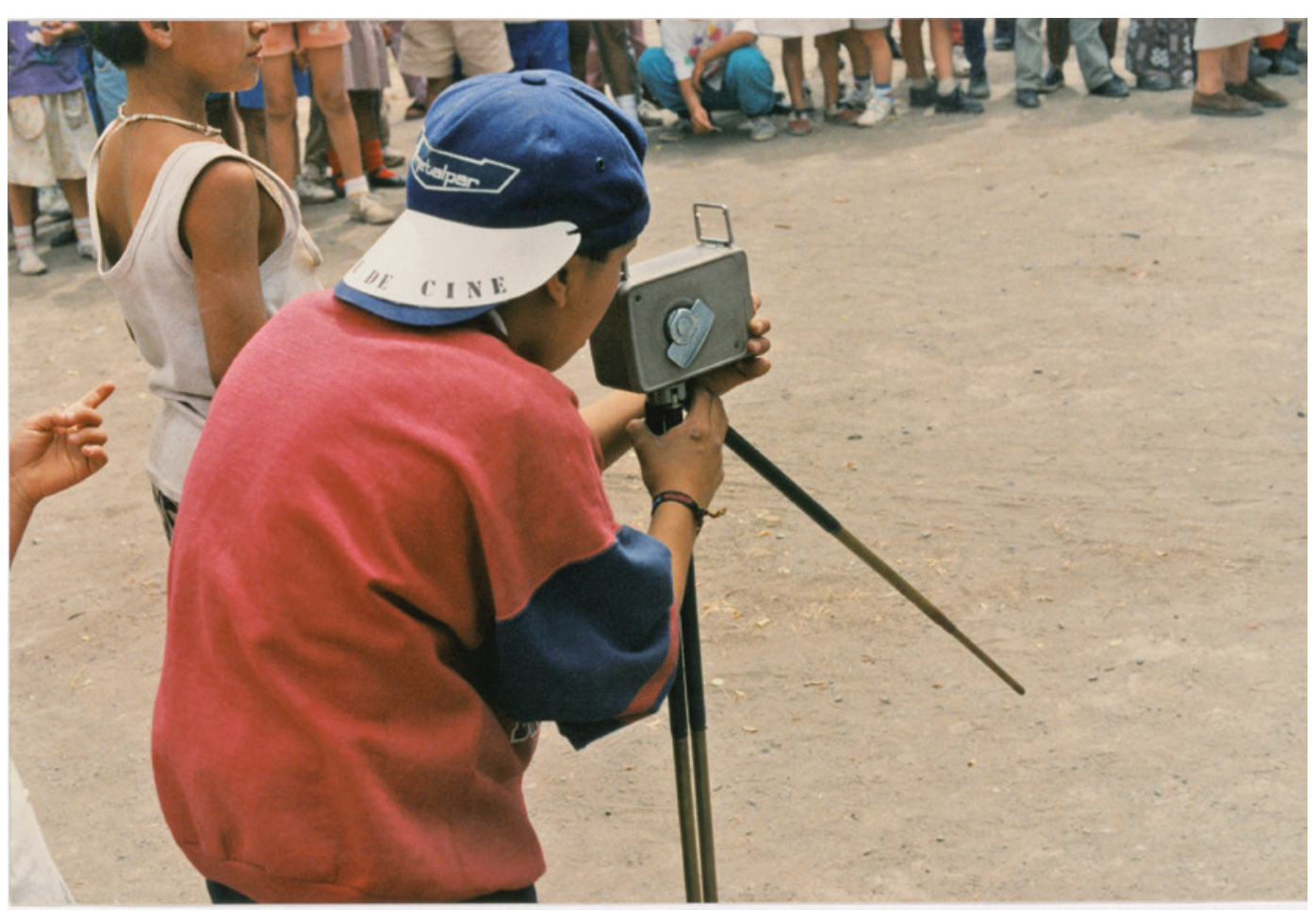

RODAJE DE "BLANCA NIEVE Y IOS SIETE ENANITOS"

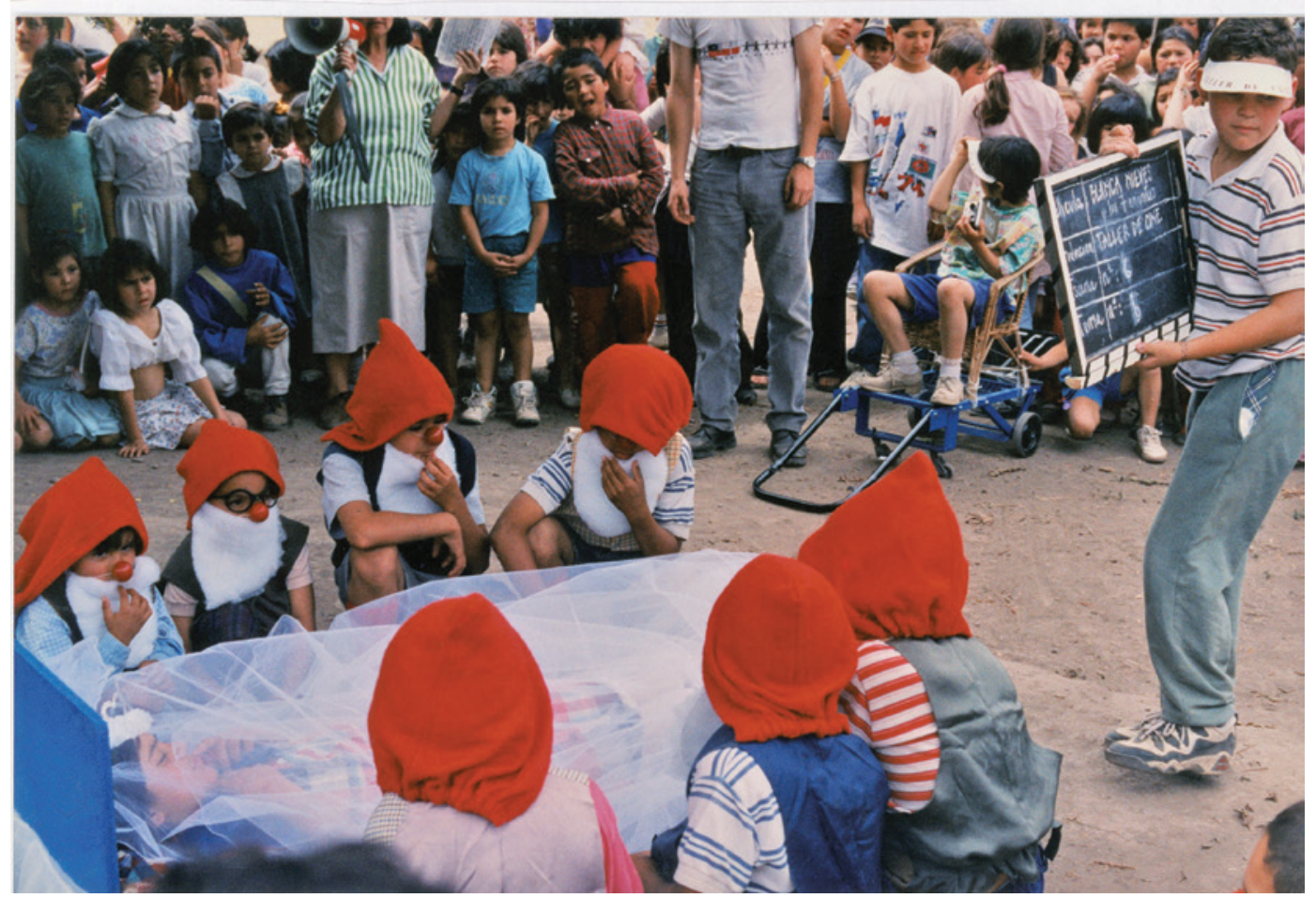

Filming Snow White and the Seven Dwarves. Ciudad del Niño, 1996

Three Stooges. They wrecked tables, easels and posters. We had no other choice than to respond, given the fact that these actions would have carried on. We enlisted some social workers, whose presence made matters worse. This also caused problems among the orphanage officials, who decided to leave en masse when we asked them not to tell the children what they had to create and not to seize their drawings as a punishment for bad behaviour. Following on from this I tried a different approach, attending the 


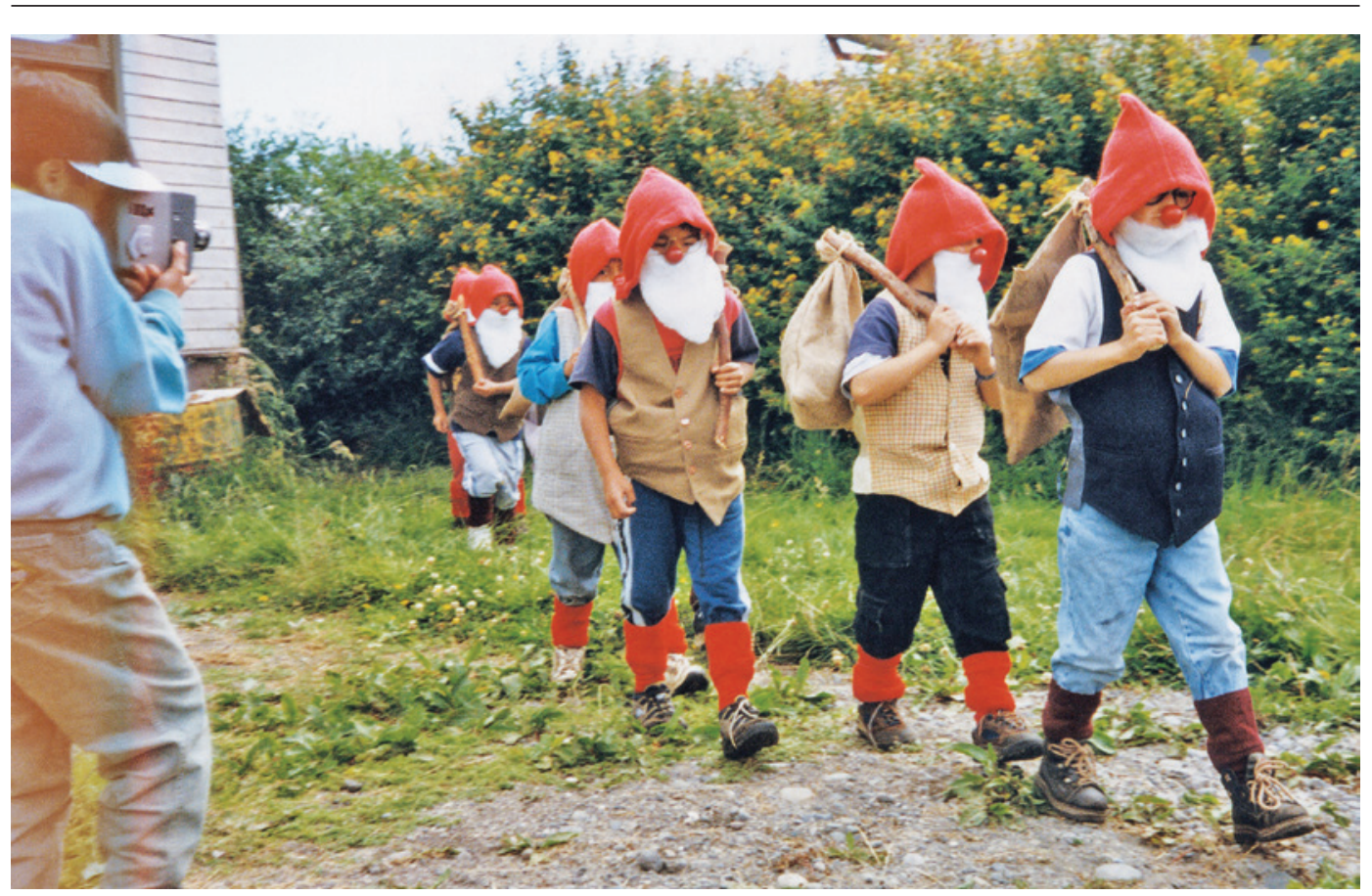

Filming Snow White and the Seven Dwarves. Queilén, 2000

orphanage's lessons every Thursday to inform the different year groups about the activities they would be doing on the Saturday at the Taller de Cine. In addition to this, I asked the teachers to work in collaboration with our programme.

Two weeks later we witnessed a change, immediately after the screening of The Red Balloon. The opening minutes did not differ greatly from previous screenings, that is to say, there was lots of noise, laughing and pushing. But five minutes into the film the children's attention was absolute. Half an hour of deep emotion ensued. As soon as the film ended, there was a loud ovation for the film's protagonist with whom the children had identified. We had the same experience with Chaplin's The Kid, for they soon realized that the main protagonist was a single mother and that the child was an orphan. In other words, they grasped that they were living in similar circumstances to those shown in the film. For this particular screening of The Kid we had musician Catalina Claro on the piano, lit by candlelight. The children sat in complete silence, moved, utterly captivated, confirming that film is a social experience. Sometimes I think that these children had never had such a powerful experience before.

Without the children fully realizing it, their work gradually increased their selfesteem and self-confidence. Our team increased the number of leading roles in our activities whenever this was possible: we had 20 chefs with professional aprons and hats, 20 cooks with their own aprons and chef's hats, 20 film ushers with their own uniforms and torches, 10 sweet-sellers with their own boxes, 10 cameramen, 10 illuminators, 10 make-up artists ... This new approach contributed to the children's conscientious engagement with subsequent creative tasks.

At Ciudad del Niño all the children returned home or to foster homes for Christmas. Only 25 girls remained at the orphanage since they could not be 'placed' anywhere. We offered to organize the Christmas Eve celebrations, joining the children at dinner time and handing out presents provided by the institution. It was getting dark when a mother arrived late to collect her three daughters and made her way straight to the dormitories. On entering the room she swore rudely at her eldest daughter, 
who was 13 , and then hit her, leaving her there. The youngest sister, who was only 5 , came to get me in the dining room so that I could go back to the dormitories with her. There I saw her sister, crying her eyes out, face swollen, bruises on her leg, saying she couldn't get up and that she hated her mother. The carers told me that 'it was always the same'. We all helped to get the girl ready for the party. In safe company, her situation improved throughout the evening.

Some time ago, I remember attending a dinner party at a friend's house where all the guests were discussing when Paul McCartney visited Chile last. Nobody could remember, with the exception of the matriarch of the house, who confidently said: 'it was in 1993'. And, as it happened, Paul McCartney had been in Ciudad del Niño. She recounted that not all tickets had been sold for his concert and that as the promoters had to fill the venue's seats they used the orphans of Ciudad del Niño. I believe that the children at Ciudad del Niño loved our work because we treated them differently: the workshop was about them, we were honest with them, and we joined them every Saturday for 25 consecutive weeks.

The power of art reaches children. It is possible to see how they make progress week after week: paying more attention, engaging with images, working hard on their tasks and enjoying films. As the workshops develop, they start asking who the director is or the year in which a particular film was made. In stark contrast, during the first sessions they make mistakes with basic information (for instance, the country of origin of a film), they never answer what they are asked and their levels of aggressive behaviour are at their highest.

Humour, and, more particularly, humour in films, soon becomes a survival strategy for the group, for they learn to accept their differences, to be respectful towards those who take longer to do a task or who have difficulties in expressing themselves. I would like to think that, in addition to learning how to look at images, they are learning about themselves.

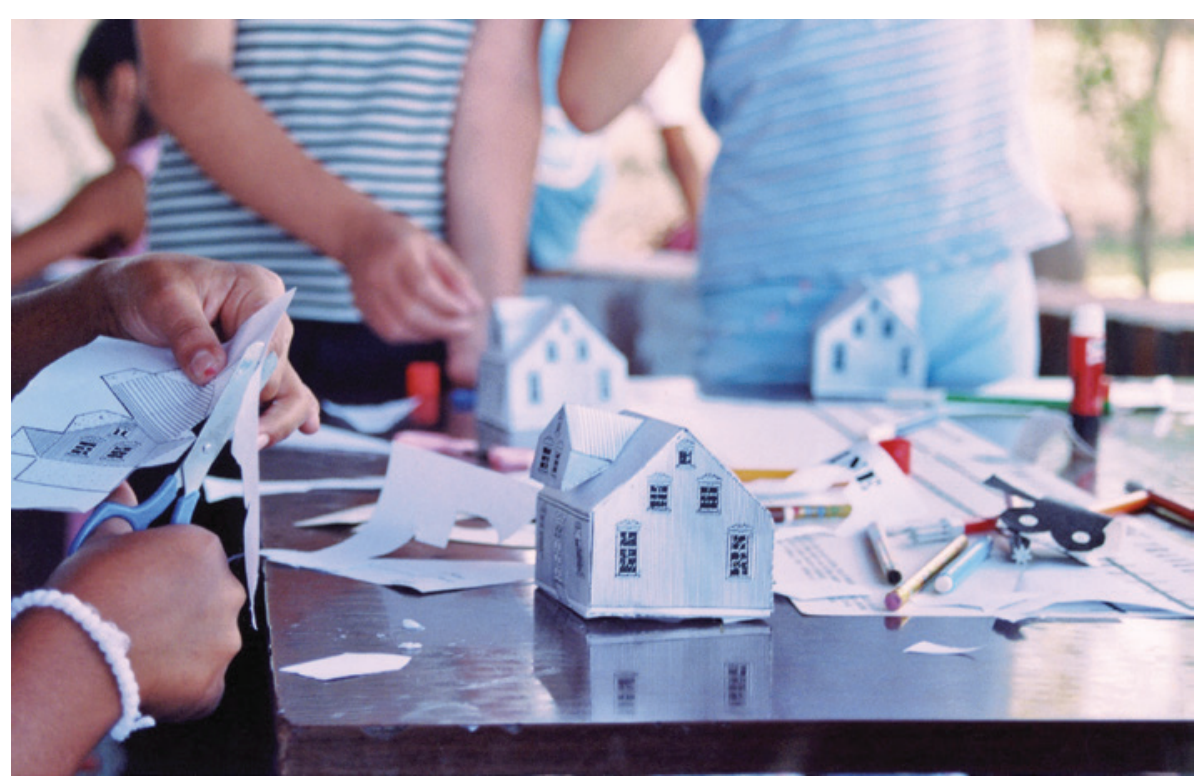

For the children of Puerto Octay we prepared some additional material, which consisted of three stencils featuring traditional buildings in the area at the beginning of the twentieth century. Participants could paint, cut, fold and assemble each of the houses. The stencils had been designed by architect Oscar Ortega from the School of Architecture at the University of Chile who was working on a research project in Puerto Octay at that time. Jorge Yarur, La Pintana, 2002 


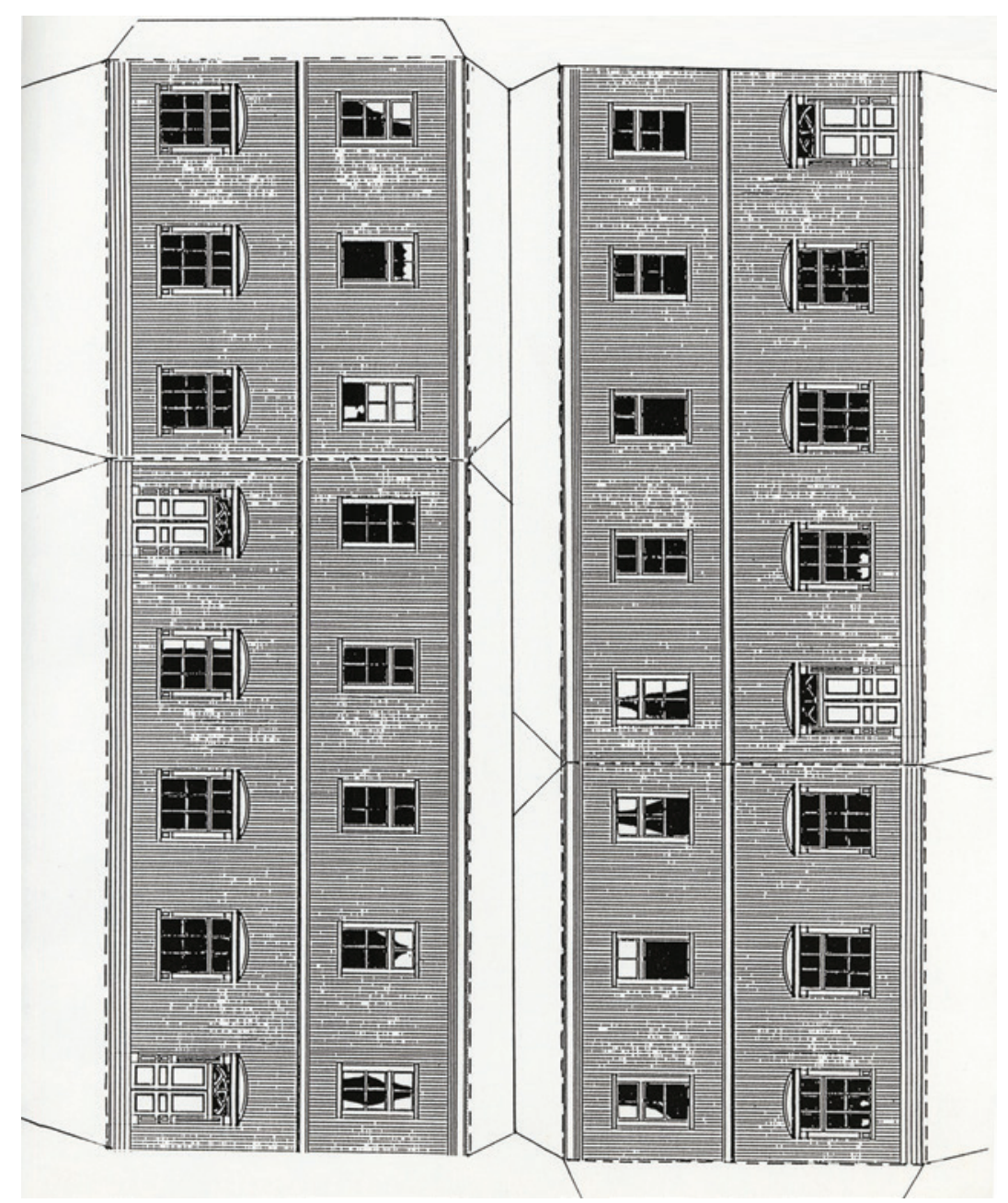

Building stencils used in workshops

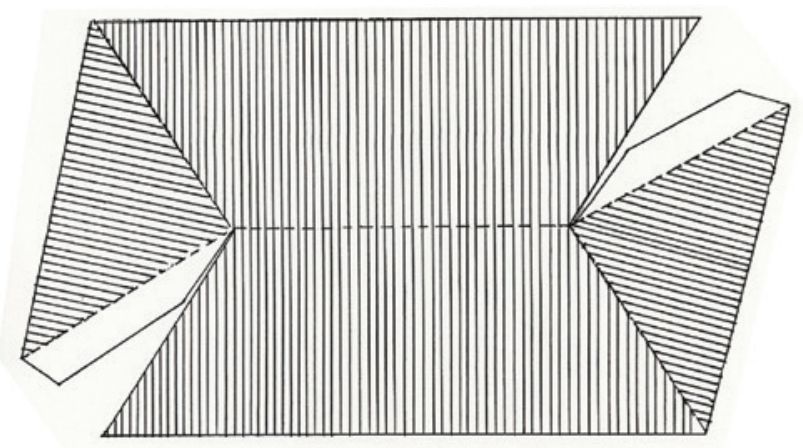

An example of the stencils used in workshops

Many children at the Taller de Cine ask me why I sweep the hall entrance every day before starting any workshop activity. (I always give myself simple tasks while the rest of the team load and unload the equipment, set the furniture up, and so on, but this is not my answer to the children.) I always reply that we are welcoming them, that they are our guests and that we want them to enter a clean space. At first, they find it amusing when they see me tidying up the bottles and other rubbish left from the previous night, 

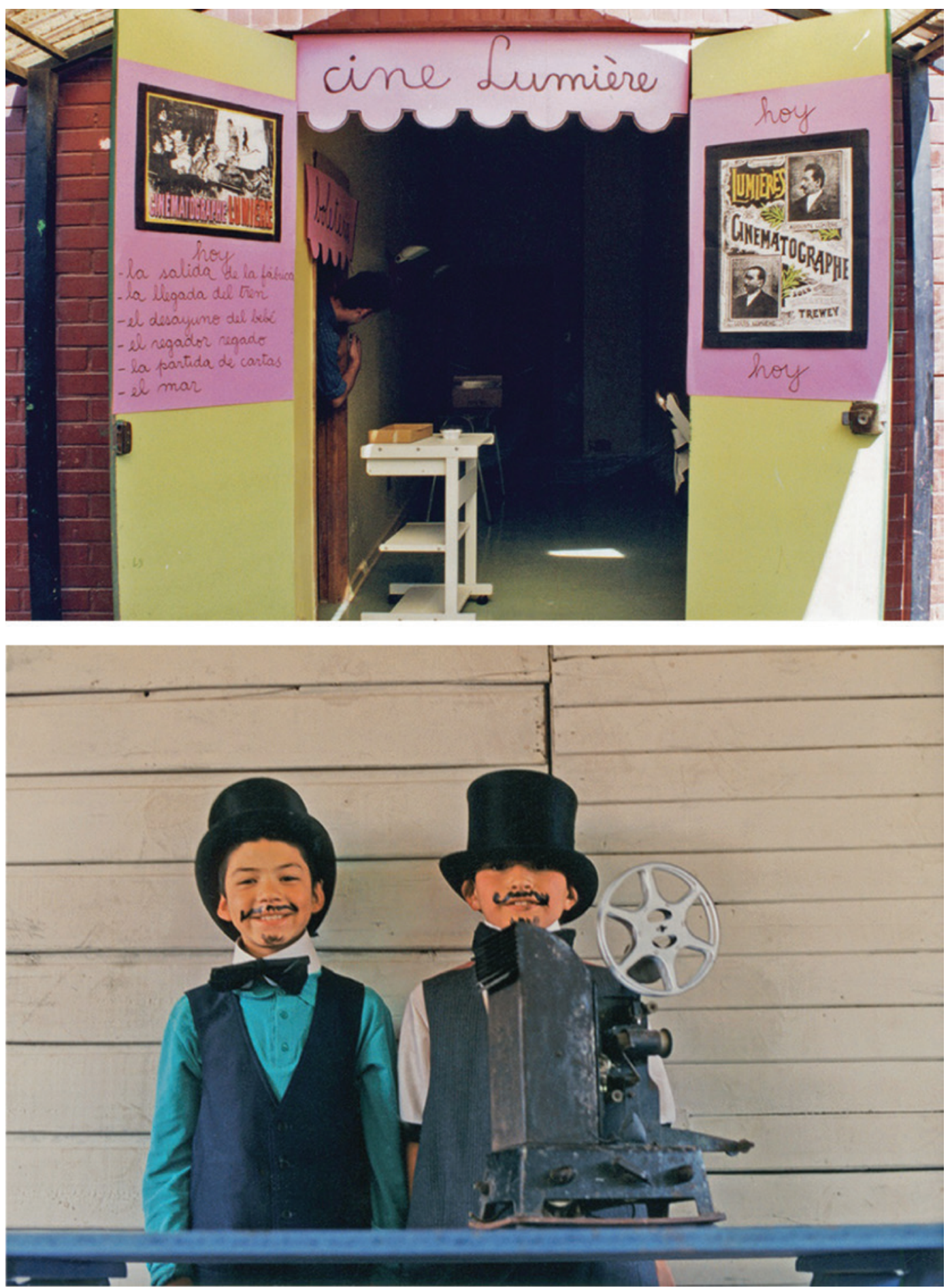

Week by week the children created several games with moving images until they reached the invention of cinema. On that day two brothers dressed as Louis and Auguste Lumière (seen behind the box-office counter and next to their projector) while the rest of the children, dressed in the fashion of the late 1890s, took to their seats to view on the screen the exact film that the Lumières first projected in Paris. Although our audience had already seen silent movies at the workshops, they were curious about the precariousness of the Lumières' work (one-minutelong movies, one shot, one location) and, perhaps, prompted by this, a child asked: 'Were there newspapers in Chile at that time?' The answer was 'yes', El Mercurio (published in Valparaíso since 1827 and in Santiago since 1900). That same day they also discovered the extraordinary Chilean documentary Recuerdos El mineral 'EI Teniente' shot by Salvador Giambastiani in 1919. La Chimba, Recoleta, 1994 


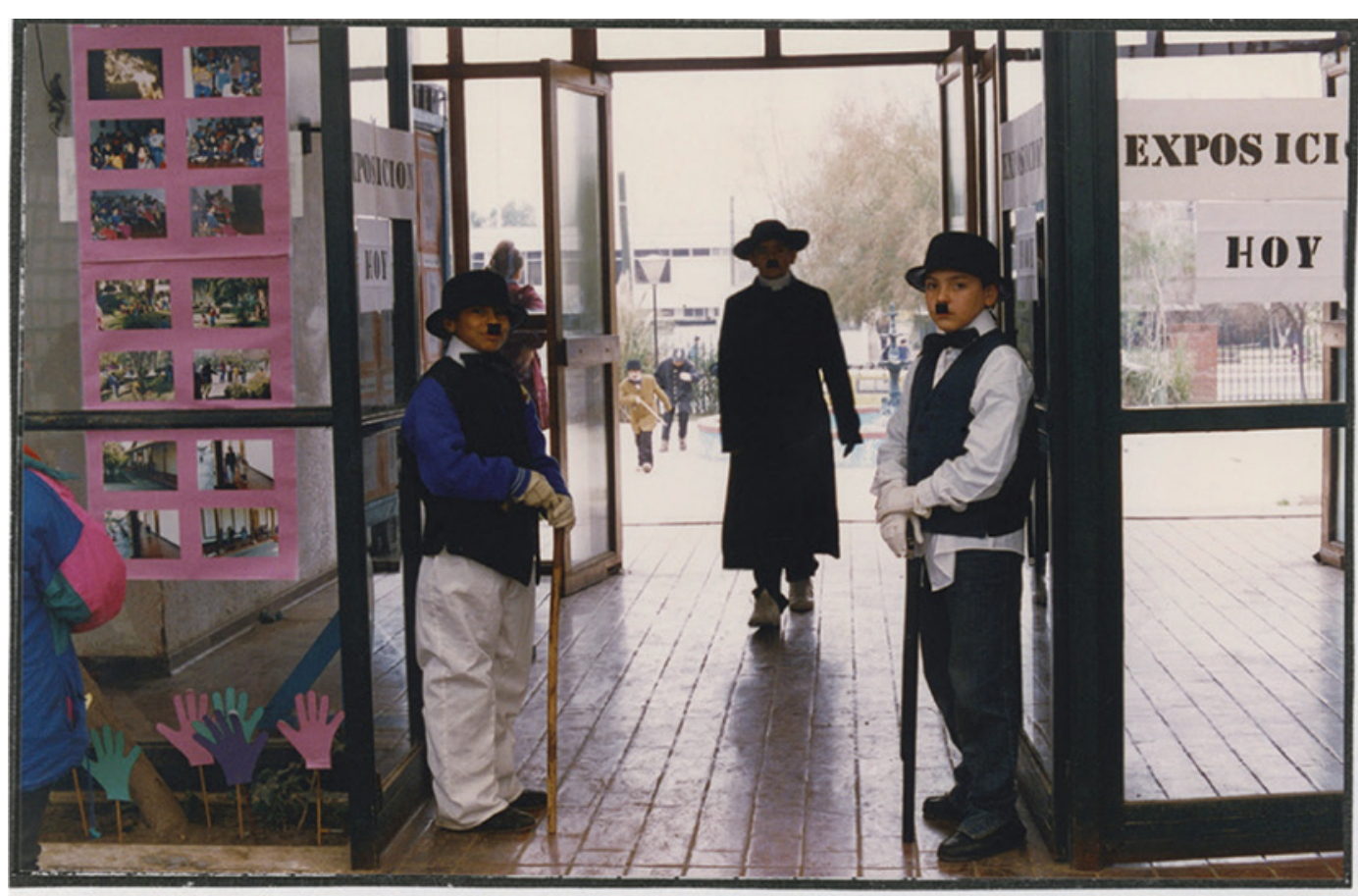

II Exposición: los invitados son recibidos formalmente y guiados al interior.

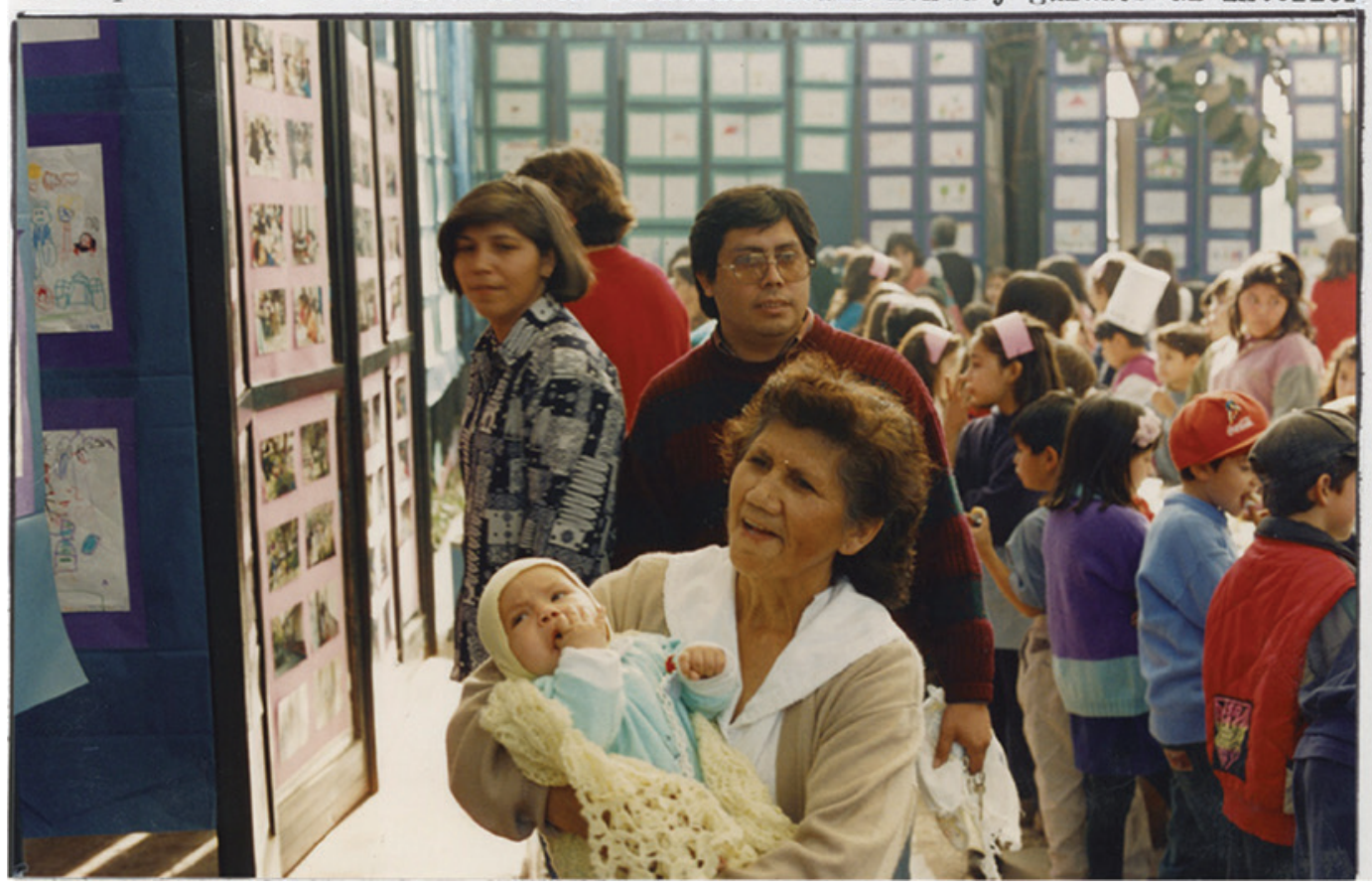

Guests are greeted formally and guided inside. Pudahuel, 1995

but soon they appreciate that this is a gesture of love. And, when they write down their views on the workshop, they say that the team were patient, treated them nicely and were good to them.

What they are saying, ultimately, is that they are not being pushed around or insulted. Violence, which, for many of the children, often seems to be their default position, decreases slowly. Although I can, of course, be firm when and if needed.

The words of an 8-year-old boy, when he completed the Taller de Cine at the parish of Santa Cruz in Los Nogales (Estación Central) in 2009, serves in these final lines to illustrate this point: 'I made really good friends. Films are fun. I liked Charles Chaplin, 
The Red Balloon. I enjoyed drawing Charles Chaplin. I enjoyed watching the films they showed us. And I am very grateful to the workshop people because I learnt and made new friends. Goodbye, Carlos Chaplin.' Twenty-four years earlier, in 1985, at the end of our first-ever workshop in the parish of Jesús Carpintero de Renca, a participant told us after the graduation ceremony: 'We were all very happy. My mum was happy. My dad made me a wooden frame for the certificate and it is now hanging on my wall. I look at it every night.' I know that violence returns and that poverty remains, but I am also well aware that cinema is one of the most enchanting experiences there is. In the darkness of the theatre, sitting next to other human beings, I am moved by the beauty of certain images. To witness children having these same experiences is one of the happiest moments in my life and perhaps the reason why I have been running this workshop for more than two decades. As I finish writing this piece - January 2012 - I still do not know where the money is coming from to run the next workshop. But I am certain of one thing: our aspirations - and those of these children - cannot be silenced.

\section{Testimonials from workshop participants, including their parents and practitioners}

I learn the same as the children do. For instance, to see the funny side of things as they are happening and to see how the children can take their work to their family. Events are unfolding in such a way that everything is continually changing and we are all learning from each other. When Alicia [Vega] told me that I could work with her, it was very important for me. Working with three hundred children or more at the same time is wonderful; seeing them entertained and eager to be there. For me the workshop is a breath of joy in the lives of these children, an opportunity to learn through playing, a right realized and a chance to let their imagination roam - Ana María Cisternas, instructor

It is great to entertain us and we don't get bored and I like colouring, drawing, cutting. I liked Miqui Maus [sic] - Workshop participant, aged 10. Parish of Santa Cruz de los Nogales, Estación Central, 2009

I thought it was hard work but it is great because it is very interesting and the teachers are very good and I learnt to share with other children - Workshop participant, aged 8. Centro Abierto Diurno Ciudad del Niño, Castro, 2002

I like it because Ms Alicia and Mr Eduardo taught us about the Lumiere Brothers who invented cinema in 1895. Then we saw a film by Chaplin, who made 80 films and we did lots of nice things and we went to the park to watch a film called The Red Balloon. I'm really grateful to Ms Alicia for having taught us so many things. Thank you. And wishing you a Happy Christmas. From my heart I'm very grateful - Workshop participant, aged 11. Ciudad del Niño, Castro, 2000

I really enjoy it because we can have fun during the summer when we are all struggling with the heat - Workshop participant, aged 12. Chuchunco, 2003

1) my mum loved it 2) my grandmother was delighted 3) and my dad was also delighted - Workshop participant, aged 8. Pudahuel, 1995

Do you think the workshop was useful for your child? 'It was very useful, because he learnt lots of "tricks" that he would show us at home. He also learnt something which 
is very important, to write his name. He learnt some stuff about cinema such as what a cinema is, things you can find in a cinema. He loves the instructor who does the juggling.' Did you notice any positive change in him? 'Well, we noticed some changes, he practised writing his name quite a lot so that he could do the same at the workshop. He came back very happy with his work from the sessions and was really happy the day he acted as one of the dwarves in Snow White. [Signed] Carmen R.' - Mother of workshop participant, aged 5, Ancud, 1999

Today we learnt about documentaries that are like films about reality. For example, Glass, Vaccine, Entre ponerle y no ponerle - Workshop participant, aged 7. Pataguas Cerro, Libertador General Bernardo O'Higgins, 1993

I made really good friends. Films are fun. I liked Charles Chaplin, The Red Balloon. I enjoyed drawing Charles Chaplin. I enjoyed watching the films they showed us. And I am very grateful to the workshop people because I learnt and made new friends - Workshop participant, aged 7. Parish of Santa Cruz de los Nogales, Estación Central, 2009

I'm sad because I'm not going to be able to go to the film workshop again. I wish they could come next year with Mr Nelson because he was lots of fun and I liked him very much. I'd like the workshop to return next year and the year after that, and if I ever go to Santiago, I'll try to visit them. Workshop participant, aged 10. Puerto Octay, 1984

The film about the little boy lost in New York [ed.: The Little Fugitive] was great. We went on a coach. I loved the Palacio de la Moneda and going to the cinema Workshop participant, aged 7. Chapel Jesús Sol Naciente, Héroes de la Concepción, Recoleta, 1993

[My son] has always been a very restless child when it comes to learning. He is always looking for new things to do and he is very responsible in this respect. As far as behaviour is concerned, he is not doing great lately because he often lies, he answers back, he is moody, [and] he is constantly fighting with his brother. When it comes to habits and manners, we need to keep an eye on him so that he behaves well as we would expect. [My son] has always been a very sociable boy. When he watches TV now, he is able to provide good comments about programmes and one can appreciate that he has learnt to do this at the workshops because we don't know how cartoons work and he does.

See you soon and a million thanks for all that you have done for our children. [My son] only missed a session because he had been grounded since he had been late for school three consecutive days. My punishment was to keep him at home rather than attending the workshop - Parents of workshop participant, aged 9. Parish Jesús Carpintero, Huamachaco, 1985

I think that the workshop brings out the goodness in all of us, and I believe that this feeling should never leave us because it teaches us the values that we have in us Workshop participant, aged 13. La Chimba, Recoleta, 1994

I thought the exhibition was very nice. The drawings are very nice, above all those of 'Charles Chaplin' who is a very famous person, known and beloved by children. Some children did very good drawings of him, with lots of details, catching his beauty. My family could not come because my mum was very busy, my dad was at work, and my 
sister was at my uncle's. Mum really wanted to come to see the drawings - Workshop participant, aged 8. San Juan Bautista, Villa La Reina, 1991

Once Alicia has agreed to organise a workshop, she is committed to running it as it was originally planned. Full commitment with dates, resources, aims. Nothing is left unfinished. She is fully aware that if resources are limited then it is better not to run a project and plan something different, shorter, more condensed which is complete in itself, with a clear beginning and a clear end. When something is done half-heartedly, it is a sign that there is no respect for other people, and any outcomes are very frustrating - Andrés Ovalle, instructor

\section{Notes on the contributor}

Alicia Vega is a film scholar and educator from Chile. She has served as a professor in film at the University of Chile and is the author of the influential Revisión del cine chileno (Reviewing Chilean Cinema) (1979). As well as serving as the director of Chile's National Film Office, she established the Children's Film Workshop, an innovative outreach film education project for children from disadvantaged communities, which conducted a pioneering series of workshops across Chile between 1985 and 2015. In 2000 Alicia received the Artistic and Cultural Merit Award from Chile's Ministry of Education and the Pedro Sienna Award in 2008, presented by the Council for Culture and the Arts, for her outstanding work as a film educator.

\section{Filmography}

The Adventurer (US 1917, Charles Chaplin)

Cien niños esperando un tren (One Hundred Children Waiting for a Train, SA 1988, Ignacio Agüero)

Crin blanc (White Mane, FR 1953, Albert Lamorisse)

El evangelio según Mateo (The Gospel According to St Matthew/Il vangelo secondo Matteo, IT 1964, Pier Paolo Pasolini)

El mineral El Teniente (SA 1919, Salvador Giambastiani)

Entre ponerle y no ponerle (To Pour a Drink or Not, SA 1971, Héctor Ríos)

Home Defense (US 1943, Walt Disney)

The Kid (US 1921, Charles Chaplin)

L'Arrivée d'un train à la Ciotat (The Arrival of a Train, FR 1896, Auguste Lumière and Louis Lumière)

La Sortie de I'usine Lumière à Lyon (Workers Leaving the Lumière Factory, FR 1895, Louis Lumière)

Le Ballon Rouge (The Red Balloon, FR 1956, Albert Lamorisse)

Music Land (US 1935, Walt Disney)

Repas de bébé (Baby's Dinner, FR 1895, Louis Lumière)

The Three Stooges (US 1949, George Cahan)

The Tramp (US 1915, Charles Chaplin)

\section{Reference}

Vega, A. (2018) Taller de cine para niños. Santiago: Ocho Libros. 